\title{
Corporate Governance Norm for SME
}

\author{
Dr. Indrajit Dube (Corresponding Author) \\ Assistant Professor, Indian Institute of Technology Kharagpur \\ Kharagpur 721302, West Bengal India \\ Ph: +91-3222-281732, Email: indrajit@rgsoipl.iitkgp.ernet.in \\ Dr. Dipa Dube \\ Assistant Professor, Indian Institute of Technology Kharagpur \\ Kharagpur 721302, West Bengal India \\ Dr. Pulak Mishra \\ Assistant Professor, Indian Institute of Technology Kharagpur
}

Kharagpur 721302, West Bengal India

Received: July 12, 2011 Accepted: August 09, 2011 DOI: 10.5296/jpag.v1i2.889

\begin{abstract}
The last few decades have witnessed several changes in the world economic system: consolidating trend of globalization and liberalization of economies; crumbling barriers to international trade and free movement of capital due to the establishment of World Trade Organization (WTO) and shifts towards market economy in contrast to the control economy or socialist economy. It was believed that market economy will be the 'mantra' for all nations, either developing or under developed, to achieve economic salvation. Destiny smiled and brought the belief to its knee and rethinking process started afresh as to what ought to be the new 'mantra'. Economic downtown indicated further that it is not the big companies, which are only efficient machineries to rotate the economic circle; rather SME's are the most trusted vehicles that will lead any economy towards salvation.

Literature across the globe suggests adoption of sustainable Corporate Governance Norms within the SME sector. On the contrary, there are strong arguments also available against introduction of such norms. In the present study we have considered the feasibility of introduction of corporate governance norms in the sector and attempted to develop, on the basis of the findings, sound and practicable solutions.

Following are the findings of the primary survey:

a. Eighty-six present of total business firms belong to the informal sector, i.e. Proprietorship and Partnership.
\end{abstract}


b. Economic liberalization encouraged many enterprises to incorporate in this sector.

c. Eighty-five percent of the enterprises in this sector are engaged in productions.

d. It is found that over the years, number of enterprises have increased their business capital, indicating thereby, that the enterprises are making profits and in sustainable business process.

e. Majority of the promoters started their business as a proprietor or partnership firm and majority of them were employed in similar type of business. The promoters/proprietors of first generations are well aware of the business risks.

f. Proprietors ordinarily are in the Management of the enterprises. Only ten percent of the enterprises said that the owners of the enterprises are not involved in day-to-day management.

g. The apex and middle management of the enterprises are occupied by comparatively less number of people. Substantially large number of the enterprises said that the apex management comprises professionally qualified people.

h. On the issue of stakeholder awareness and participation in business, almost ninety-one percent of enterprises responded that the stakeholders are aware about the activities of the firms, and nearly seventy-five percent of the enterprises welcome suggestions of their employees regarding improvement of organizational management and firm activities.

i. Fifty-one percent of the enterprises noted that their employees have undergone regular training programs. Out of that, about forty one percent enterprises send and sponsor the training programs of their employees.

j. For sixty-two percent of the enterprises, the accounts are audited by Chartered and Cost Accounting firms. Enterprises disclose the audited accounts to the other partners of the firm, members of the society, shareholders or Government authority or to the banker, those who are statutorily prescribed.

$\mathrm{k}$. On the front of regulatory compliances, it is found that the enterprises are required to go through multiple regulatory compliances.

1. The exposure of SME to information technologies is quite high. About forty-one percent of the enterprises file their regulatory returns online. Seventy Five percent of the enterprises are interested to get promotional schemes and file all regulatory returns online, if provided for.

Proposed Corporate Governance norms for SME's

A. Prepare and Publish 'Mission Statement' of Enterprises

B. Enterprise Policy Statement to Manage Business Growth

C. Enterprise Succession Plan

D. Annual Management and Accomplishment Statements

E. Management Structure and Level of Professional Qualification relevant to Industry

F. Method of Accounting and Disclosure of Audited Account

G. Stakeholder Relations and Welfare undertaken by the enterprise

H. Legal and Regulatory Compliance

Keywords: Corporate Governance, SME, Norms 


\section{Introduction}

The last few decades have witnessed several changes in the world economic system: consolidating trend of globalization and liberalization of economies; crumbling barriers to international trade and free movement of capital due to the establishment of World Trade Organization (WTO) and shifts towards market economy in contrast to controlled or socialist economy. It was believed that market economy will be the 'mantra' for all nations, either developing or under developed, to achieve economic salvation. Destiny smiled and brought the believe into it's knee and rethinking process started afresh what ought to be the new 'mantra'. Economic downtown indicated further that it is not the big companies, which are only efficient machineries to rotate the economic circle; rather SME's are the most trusted vehicles that will lead any economy towards salvation.

But that realization has possibly not brought everything best for the SME's, rather it has opened up sea of challenges. There are new business orders in the advent of Information Technology- opening up of market dominated by medium and big domestic companies, transnational companies, which has brought new line of business strategies and supply chain, hitherto unknown to traditional business model which dominates the SME's sector.

Regulatory and business operational environment poses further challenges in efficient operations and the growth of this sector. The World Bank publications, entitled 'Doing Business in 2004' provides a very good account of the business regulations and the associated cost one has to face, irrespective of size of operations, in more than 130 countries. What is needed today is business friendly environment, which would facilitate SME's to successfully reorient their business operations in tune with the few market requirements and standard business practice.

Apart from the above mentioned challenges, SME faces certain internal challenges while setting up of the business, during its growth and in succession of the organizational leadership. Setting up of the business is associated with challenges like opportunities, knowledge of business and risk factors associated with starting and running (either in nature of the financial risks or non financial risks) of the enterprise and regulatory barriers. During the growth, challenges are risks associated with market (either in Input or Output market), proper human resource expertise to match with the demand of growths and expertise in management of finance and accounts. Succession in organizational leadership is the most important challenge SME's face in absence of separation of ownership and management and failure of proper planning.

Possibly, corporate governance has greater role to play in responding to the above-mentioned challenges. With the growth of firms, there is a need to introduce professional management and governance practices. By introduction of professional managers, the separation between owner and management begins, even though it may lead to agency problem. Problem of separation of ownership is also associated with different 'business form'. For example, introduction of professional manager in proprietorship and partnership might not be feasible options. So, providing appropriate opportunity to proprietor or partner in professional orientation may be a step forward toward the introduction of professionalism within these 
type of 'business form' or enterprises. Next, for best performance from managers, governance of business units must be clear and distinct and accounting controls and internal audits will help to assess the performance of these managers.

Using a stakeholder approach, a firm is not just responsible to its owners or shareholders or members but also, to its constituency of stakeholders. These stakeholders include contractual partners, like employees, suppliers, social stakeholders, like the members of the community and the environment. This approach emphasizes long term performance, enhancing contributions by stakeholders and also view corporations as socially responsible institutions. Thus, an appraisal of a firm will not only include financial performance but also employment, market share and growth in trading relations with suppliers and purchasers.

Corporate governance allows firms to prepare for their future expansion and sustainable growth. The core values of transparency and accountability will be embedded in their business culture. This culture of transparency and accountability will also indicate professional management and good governance for successful and well organized companies.

Introduction of good governance will improve SMEs' prospect of obtaining funds from banks, investors and venture capitalists. The presence of proper accounting and bookkeeping practices will increase confidence in the firm and make them less risky to invest or finance. Firms that have information disclosure tend to have healthier growth rates and ratios of ordinary profits to that of capital, than firms who do not do so. Firms also will become increasingly committed to business efficiency due to the presence of external supervisory third-parties.

Insolvency in SMEs is very high because of lack of professional management. It has direct impact on country's economy and work force. In greater term, any investment is a result of the public savings and insolvency denotes losing of net worth of enterprise meaning thereby loss of public savings. On the other hand, $80 \%$ of work force of the country is employed in these sectors. So, loss of ventures has very strong impact on country's socio - economic conditions.

\section{Objective of Study}

The objective of study lies in generation of knowledge base for corporate governance of SME's and development of sustainable and adaptable corporate governance norms for these enterprises. It is a common belief that corporate governance will help to bring efficiency and sustainability within the sector. Further, the study will attempt to suggest mechanism to adopt the corporate governance within the sector. Concerns for corporate governance for SME's arise out of following factors:

a. The SME's contribute almost 95 per cent of total number of establishments, about 45 per cent of the manufacturing output and 40 per cent of the total export of the country;

b. The Sector is estimated to employ about 42 million persons in over 13 million units throughout the country, i.e. about 80 per cent of the countries employment depend on 
SME's;

c. SME's access the finance from public banks and financial institutions and in turn, access the public savings through the bank;

d. There is an increasing trend of SME's contribution in GDP of the country;

e. The 'economic inclusive growth' of the country depends on the sustainable growth of SME's;

\section{Literature Survey}

Literature across the globe suggests in favour of adoption of Corporate Governance Norms within the sector. There are also strong arguments available against introduction of such norms in the sector. In the present study we will consider those arguments and their findings in order to develop corporate governance norms for the Indian SME's. It is also worth to unearth what we understand by corporate governance.

Academia attempted to shape the concept of corporate governance in the beginning of last century; but corporate governance as a business practice was adopted only two decades back. As a method of business practice, it was examined several times by the different expert committees. The committees attempted to define, describe and provide the meaning of corporate governance based on the social, economy and the political culture of the state. Some of them described the attributes of corporate governance.

It will be interesting to note some of the contextual definitions and meaning of corporate governance in different jurisdiction:

\subsection{United Kingdom}

Cadbury Committee Report on 'The Financial Aspect of The Corporate Governance’ 1992:

'Corporate Governance is the system by which companies are directed and controlled. Boards of director is responsible for governance of the companies. The shareholder's role in governance is to appoint directors and the auditors and to satisfy themselves that an appropriate governance structure is in place. The responsibility of the board includes setting the company's strategic aims, providing the leadership to put them into effect, supervising the management of the business and reporting to shareholder on their stewardship. The board's actions subject to laws, regulations and the shareholders in general meeting.”

Hampel “Committee on Corporate Governance” January 1998 described Corporate Governance:

The importance of corporate governance lies in its contribution both to business prosperity and to accountability. ...

Business prosperity cannot be commanded. People, teamwork, leadership, enterprise, experience and skills are what really produce prosperity. There is no single formula to weld these together, and it is dangerous to encourage the belief that rules and regulations about structure will deliver success. Accountability by contrast does require appropriate rules and 
regulations, in which disclosure is the most important element.

Good governance ensures that constituencies (stakeholders) with a relevant interest in the company’s business are fully taken into account. ...

Good corporate governance is not just a matter of prescribing particular corporate structures and complying with a number of hard and fast rules. There is a need for broad principles. All concerned should then apply these flexibly and with common sense to the varying circumstances of individual companies.

\subsection{United States of America}

The Business Roundtable “On Principles of Corporate Governance”, 2004 described it as:

“... [C]orporate governance is through conscientious and forward looking action by business community that focuses on generating long term value with higher degree of indignity. ...

Effective Corporate Governance is requires a clear understanding of the respective role of board and the senior management and their relationship with other corporate structure. The relation of board management with stockholders should be characterized by candor; their relationships with employees should be characterized by fairness; their relationships with the communities in which they operate should be characterized by good citizenship; and their relationships with government should be characterized by a commitment to compliance.

\subsection{Australia}

AXC Corporate Governance Council on "Principles of Good Corporate Governance and Best Practice Recommendation” 2003 defines Corporate Governance as:

"Corporate governance is the system by which companies are directed and managed. It influences how the objectives of the company are set and achieved, how risk is monitored and assessed, and how performance is optimised.

Good corporate governance structures encourage companies to create value (through entrepreneurism, innovation, development and exploration) and provide accountability and control systems commensurate with the risks involved."

In 2007 AXC Corporate Governance Council revisited its earlier definition and read as:

"Corporate governance is "the framework of rules, relationships, systems and processes within and by which authority is exercised and controlled in corporations". It encompasses the mechanisms by which companies, and those in control, are held to be accountable. Corporate governance influences how the objectives of the company are set and achieved, how risk is monitored and assessed, and how performance is optimised.

Effective corporate governance structures encourage companies to create value, through entrepreneurialism, innovation, development and exploration, and provide accountability and control systems commensurate with the risks involved.”

Horwth 2002 Corporate Governance Report adopted the definition of Pat Barrett, Auditor 
General of Australia in November 2007,

"Corporate governance is largely about organisational and management performance. Simply put, corporate governance is about how an organisation is managed, its corporate and other structures, its culture, its policies and the ways in which it deals with its various stakeholders. It is concerned with structures and processes for decision-making and with the control and behaviour that support effective accountability for performance outcomes/results.”

\subsection{Canada}

Joint Committee on Corporate Governance, 2001, viewed Corporate Governance in following way:

"The objective of good governance is to promote strong, viable and competitive corporations.

$\cdots$

These include assessing and approving the strategic direction of the company, ensuring that management has in place appropriate processes for risk assessment, management and internal control, monitoring performance against agreed benchmarks, and assuring the integrity of financial reports. When boards add value by fulfilling their responsibilities in these areas, it will result in greater transparency and understanding of a company's situation by its major stakeholders.”

\subsection{South Africa}

King Report on Corporate Governance looks at it from leadership point of view:

“Corporate governance is essentially about leadership:

a. Leadership for efficiency in order for companies to compete effectively in the global economy, and thereby create jobs;

b. Leadership for probity because investors require confidence and assurance that the management of a company will behave honestly and with integrity in regard to their shareowners and others;

c. Leadership with responsibility as companies are increasingly called upon to address legitimate social concerns relating to their activities; and

d. Leadership that is both transparent and accountable because otherwise business leaders cannot be trusted and this will lead to the decline of companies and the ultimate demise of a country's economy.

e. Monitoring and supervision across the entire spectrum of economic and commercial enterprise is impossible by any measure, and thus the recommendations contained in this Report remain self-regulatory - although conformance can be encouraged in various ways. ...” 


\subsection{India}

Kumarmanglam Birla Committee described the contours of corporate governance instead of defining or giving a meaning of it.

"The Committee has identified the three key constituents of corporate governance as the Shareholders, the Board of Directors and the Management and has attempted to identify in respect of each of these constituents, their roles and responsibilities as also their rights in the context of good corporate governance. Fundamental to this examination and permeating throughout this exercise is the recognition of the three key aspects of corporate governance, namely; accountability, transparency and equality of treatment for all stakeholders.”

Narayan Murti Committee on "Report of the SEBI Committee on Corporate Governance" commented on Corporate Governance in the following manner:

"Corporation is a congregation of various stakeholders, namely, customers, employees, investors, vendor partners, government and society. A corporation should be fair and transparent to its stakeholders in all its transactions. This has become imperative in today's globalized business world where corporations need to access global pools of capital, need to attract and retain the best human capital from various parts of the world, need to partner with vendors on mega collaborations and need to live in harmony with the community. Unless a corporation embraces and demonstrates ethical conduct, it will not be able to succeed.

Corporate governance is about ethical conduct in business. Ethics is concerned with the code of values and principles that enables a person to choose between right and wrong, and therefore, select from alternative courses of action. Further, ethical dilemmas arise from conflicting interests of the parties involved. In this regard, managers make decisions based on a set of principles influenced by the values, context and culture of the organization. Ethical leadership is good for business as the organization is seen to conduct its business in line with the expectations of all stakeholders.

Corporate governance is beyond the realm of law. It stems from the culture and mindset of management, and cannot be regulated by legislation alone. Corporate governance deals with conducting the affairs of a company such that there is fairness to all stakeholders and that its actions benefit the greatest number of stakeholders. It is about openness, integrity and accountability. What legislation can and should do, is to lay down a common framework - the "form" to ensure standards. The "substance" will ultimately determine the credibility and integrity of the process. Substance is inexorably linked to the mindset and ethical standards of management."

OECD in 2004 revised the principles of corporate governance and fine-tuned the principles under the following headings:

a. The Corporate governance framework should promote transparent and efficient market, be consistent with the rule of law and clearly articulate the division of responsibilities among different supervisory, regulatory and enforcement authority.

b. The corporate governance framework should protect and facilitate the exercise of 
shareholders' rights

c. The corporate governance framework should ensure the equitable treatment of all shareholders, including minority and foreign shareholders. All shareholders should have the opportunity to obtain effective redress for violation of their rights.

d. The corporate governance framework should recognized the rights of shareholders establish by law or through mutual agreement and encourage active co-operation between corporations and stakeholders in creating wealth, jobs and the sustainability of financially sound enterprises.

e. The corporate governance framework should ensure that timely and accurate disclosure is made on all material meters regarding ownership, and governance of the company.

f. The corporate governance framework should ensure the strategic guidance of the company, the effective monitoring of management by the board, and the board's accountability to the company and shareholders.

The reports of different committees laid down the basic principles of corporate governance and prescribed the modalities of governance in public company, not including the SME sector.

Committee for Trade, Industry and Enterprise Development of Economic Commission For Europe organized 'Expert meeting on good governance for SMEs' on $1^{\text {st }}$ to $2^{\text {nd }}$ April 2004 to deliberate on importance of introduction of Corporate Governance in SMEs Sector. It also discussed about what ought to be the policy regarding corporate governance of SME's in the European Union. It was stated that more than $90 \%$ of all enterprises in the region were SMEs'. Some of the papers presented in the meeting have been reviewed for this study.

'Discussion Paper for The Expert Meeting on Good Governance For SME's' started with the comments by Brigita Schmognerova, “... Adequate government policy should be focused on developing a business friendly environment, but at the same time targeted policies are needed, like (1) improving of the SME Sector to financing (risk Capital, Micro-lending, Instruments for financing innovation), and (2) promoting good governance including social and environmental responsibility.”

The paper noted the challenges faced by the SME's in the emergence of the global economic order and its impact on the sector. "... [I]t provides new opportunities for expansion and growth by taking advantages of international market possibilities, and challenges to adapt and become internationally competitive. For the majority, however, growing economic globalization is basically competing with foreign enterprises and this is an inward process that brings competitive challenges and threats. Majority of the SMEs are on the brink of failure, in surviving the globalization process." The paper further emphasized that "Good Governance for SME's means practices that could encourage the establishment of SMEs methods that are useful for start-up business to tackle the challenges of market'. 
The development of this sector is critical to the overall economic growth of transitional economies. SME's create jobs, employ workers laid off from decline of restructured enterprises and generate government revenue. They also establish a solid foundation for market-based growth by creating a large class of stakeholder.

To support the growth of SMEs', government should implement a number of initiatives to create a business - friendly economic environment based on strong legislation and favorite business support Institutions. There is a need to improve SMEs' access to the capital, to build local business services and to access to $R \& D$ and internationalization.

To promote corporate governance within SME's, the paper emphasized upon Institutional Capacity Building. It emphasized on four areas, firstly, a legal infrastructure appropriate to the market conditions; secondly, the creation of a legal framework to facilitate the development of entrepreneurship; thirdly, the creation of commodity, capital and labour market, fourthly, creation of business support infrastructure conducive to the creation and development of new and small enterprises.

Though the paper ended with a positive note about the importance of Corporate Governance in this sector, but failed to determine the indices of corporate governance and how to implement the same.

The paper titled 'Corporate Governance in Advance Market Economies: Understanding Important Contingencies' concentrated on comparative analysis of corporate governance of SMEs in Advance Market Economics and Transition Economics and made certain interesting observations. The author observed, 'The design of a governance system must consider the actors involved and the context for which the system is designed. Important contextual factors are the national and cultural setting, and size of the firms'... 'It is of crucial importance to understand the actor and the context in transition economies when designing governance system ...' It emphasized that the life circle (i.e. entrepreneurial stage, a collective stage, a formalisation and control stage and an elaboration of structure stage.) of different firms has important bearing in determination of governance factor.

The paper ended with the note "Good governance is an important element in developing a market economy and in promoting economic growth, especially in emerging and transitioning economies (Judge et al 2003, McCarthy and Puffer 2003). SMEs may however be less likely to have resources to accomplish corporate governance developments, and SME managers may also run their companies as if it were only their stakes that were involved and satisfying own interest to the detriments of other main stakeholders and the company as a whole (Jones and Butler 1992, Markman, Balkin and Schjoedt 2001). This implies that there may be need for public education efforts to promote the understanding of principles of good governance in SMEs. There may also be a need to promote efforts to identify board members with diverse talents and experience, including women and others that often are excluded”.

Prof. David Smallbone, in 'Institution, Governance and SME Development in Transition Economies' attempted to explain the factors that influence corporate governance of SME's. According to him 'Governance has been defined as "conscious collective action extending 
beyond government deploying, for example, the capacities of business, community groups and academic institutions”. Governance is concerned with the rules, procedures and practice affecting how power is exercised. These issues are central to the democratic process, because they influence the legitimacy and effectiveness of institutions, ..., can have the major impact in the entrepreneurship development.'

On the issue of entrepreneurship and governance policy, he has identified certain parameters: first, macroeconomic policy, since the microeconomic environment affects the willingness and ability of entrepreneurs to invest, particularly in projects that may take some time to produce return; secondly, the cost of legislative and regulatory compliance, which can fall disproportionately heavily on smaller enterprises; thirdly, tax policies, including the tax burden but also the cost of the compliance that can be affected by the frequency with which the total tax burden but also the tax of compliance, fourthly, the influence of government on the development of market institution, such as bank and other financial intermediaries, business support and training organisations; finally, the influence of the government on the value placed on enterprise and entrepreneurship in society, which in the long term is affected by the curriculum and methods of teaching in the education system, and also by the stance of government towards business and property ownership.

He stresses upon five key principles of good governance:

- Openness, which means that institutions should operate in an open and accessible manner;

- Participation, throughout the policy chain, from conception to implementation;

- Accountability, with clearly defined roles for institutions in legislative and executive process, with each institution explaining and taking responsibility for what it does;

- Effectiveness, emphasizing that policies must be effective in delivering what is needed on the basis of clear objective and assessment of future impact.

- Coherence, policies and actions, as well, as between policies.

'The effective institutionalization of policy with respect to entrepreneurship needs to incorporate the partnership principle. In mature market economies, self-governing, self-regulating organisations act as professional intermediaries in the process of dialogue between government and entrepreneurs, in order to ensure that the interests of businesses are taken into account in the decision making of public authorities at different levels. ...'

He has concluded that the state has greater role to play through its different institutions in development of corporate governance for SME's. According to him, strengthening the external agency will lead to strengthening of internal governance of SMEs'.

Australia author Dr. A D Clarke in his article, 'SMEs and Corporate Governance: Politics, Resources and Trickle-Down Effects'based his observation upon the work of John Farrer and stated that 'The core or irreducible nature of SMEs is difficult to locate, but there are facets that are invariably common to them: family ownership and management, a lack of strict 
separation between owners and managers, and the management of particular family issues, include dispute resolution and succession planning.' He further pointed out that 'The resource implications of corporate governance compliance are far more marked for SMEs. With smaller revenue bases, and less specialization and expertise at their disposal, the compliance demands of corporate governance will invariably require 'frontline' managers to divert from their mainstream roles. ... The reason for this lack of specific or quantifiable benefit for SMEs, goes back to the fact that the central thrust of company law and corporate governance is to retain the contractual distance between management and the owners. Where there is a great deal of overlap between the two such that the structure is more akin to a partnership, the reports by managers are essentially going to be themselves as owners'.

He concluded with following observations:

- 'A principles based approach to corporate governance provision, rather than a rule driven, minutiae obsessed orthodoxy. That is, less legal influence and more credence given to cultural imperatives, economic theory and political constructs that informs and shape corporate governance.

- A two-step governance system; one for large firms and one for SMEs. That is, a governance arrangement better attuned to the market place, which it serves. The hallmarks of the Australian market need to be explicitly acknowledged in this project: a relatively small capital market, and a market in which there is a gulf between the large listed companies and the rest. This binary divide should provide opportunities for simple, principle based governance for SMEs that can 'weave' its way up to large firms, rather than a continuation of the trickle down approach from large firms to SMEs.

- Specific and simple SME governance arrangements that reflect their particular form and architecture. These forms include the predominance of family based firms with a strong crossover between managers and owners. This provision would recognize the largely fictional notion of separation that is, in fact, more apposite for large and listed firms.

- The possibilities of recognizing a form of hybrid partnership- company arrangement for SMEs. This can be achieved by a separate set of rules, or by specific legislation that recognizes that at the margins, the partnership form and the corporate model do in fact overlap. Rather than the complex set of rules that are theoretically applicable, but badly fitted in practice to SMEs, there should be a differentiated approach that is informed by the basic, but imperative notion, of differential architecture. The domain occupied by SMEs is unique: not part of amorphous arrangement which bundles all firms together in an apparently unproblematic way'.

\section{Issues of Corporate Governance}

Issues of Corporate Governance for SME's are possibly the most debated ones as discussed above. The debates are not on the merits regarding need of corporate governance for the sector, rather on what are the appropriate governance norms for the sector and how to 
implement the same. According to researchers, the same is because of some definite characteristics of the sector. These may be the business form, capital structure and man power and market accessible for purposes of credit, raw material and supply.

The study of 'Business Form' is quite interesting. Ninety-four percent of the sector is dominated by 'informal business forms', i.e., proprietorship, Hindu undivided family and partnership. The second category of 'business form' include co-operatives, societies and trusts while the last category is the 'formal business form' like private and public companies, which are in minority in this sector. The first category 'business form' has mainly developed through customary processes [except partnership]. Again, trust is constituted, either through customary or statutory processes and originally this 'organizational form' developed, not as business, rather as 'institution for charity'.

Other business forms developed out of the different organizational laws like India Partnership Act 1932, Co-operative Societies Act, 1942 and Companies Act 1956. These acts were passed as organizational laws in different stages of economic history. But, these laws are silent regarding the issues of internal structure of the organization.

Capital structure of these organizations also varies widely. The capital variation may be even as low as ten thousand rupees to more than ten crores of rupees. Again, the human resource of this sector may vary from one person to couple of hundreds. So, the dispersions regarding capital and human resources are very high in this sector.

In most situations, SME's access the unorganized market for the purposes of credit, supply of raw material and finished goods. This in turn creates impact on their business practice, i.e. accounting practice, understating of business risk and its management. The sector is primarily dominated by traditional model of business practice and averse towards modern business process because of fear of increasing cost and other disadvantages with might be associated with such modern business process.

Relying on the above issues, the question is to what extent principles of modern corporate governance are applicable to this sector? Should there be different corporate governance for different business form within the sector?

Traditionally, corporate governance has evolved around the contract theory and agency problem based on separation of ownership and management. So, all standard texts, review and research papers and business committee reports base their arguments around agency problem only. The company/corporate law across the jurisdictions laid down the basic governing relation between owner and managers, whereas other relations like moral and beneficiary, economic and succession were left to mutual understanding between owners and managers. So, the objective of theory building was to strengthen the protection of interests of shareholders and other stakeholders against the management supremacy.

Over the years, theoretical boundaries of the corporate expanded on the issues like relationship management between the different constituents of corporate. So, the objective of corporate governance not only lay in protection of the interest of the shareholders but towards economic and social prosperity. And the importance of corporate governance of SMEs 
became important from this perspective.

There is hardly any 'business form' in this section that differentiates the ownership from management; so, principles of corporate governance based on the agency problem are not of importance for this sector. Rather, principles developed to achieve efficiency in the enterprise are suitable for this sector. Therefore, difference of business forms need not suggest different set of corporate governance norms within the sector.

\section{Research Questions}

Based on the above opinion, observation and background study, the researchers framed the following 'research questions':

A. What organizational structures are prevalent across the sector?

B. What is the capital intensity of these enterprises?

C. What discloser pattern these enterprises generally adopt?

D. What are the legal compliances they are subjected to?

E. What ought to be the simple corporate governance norms which will reduce cost and increase efficiency?

F. How will the government ensure adaptability of corporate governance norm in SME's?

\section{Research Methodology}

For the purpose of defining SME, the researchers relied upon Micro, Small and Medium Enterprises Development Act 2006. The act has defined enterprises under Section 2 Clause 2 '... means an industrial undertaking or a business concern or any other establishment, by whatever name called, engaged in the manufacture or production of goods, in any manner, pertaining to any industry specified in the First Schedule to the Industries (Development and Regulation) Act, 1951(65 of 1951) or engaged in providing or rendering of any service or services'.

Section 7 of the said act provides 'forms of business' which may be included within the meaning of 'enterprise’ and also classified according to capital. It reads like:

"Notwithstanding anything contained in section 11B of the Industries (Development and Regulation) Act, 1951(65 of 1951), the Central Government may, for the purposes of this Act, by notification and having regard to the provisions of sub-sections (4) and (5), classify any class or classes of enterprises, whether proprietorship, Hindu undivided family, association of persons, co-operative society, partnership firm, company or undertaking, by whatever name called,--

(a) in the case of the enterprises engaged in the manufacture or production of goods pertaining to any industry specified in the First Schedule to the Industries (Development and Regulation) Act, 1951(65 of 1951), as-- 
(i) A micro enterprise, where the investment in plant and machinery does not exceed twenty-five lakh rupees;

(ii) A small enterprise, where the investment in plant and machinery is more than twenty-five lakh rupees but does not exceed five crore rupees; or

(iii) A medium enterprise, where the investment in plant and machinery is more than five crore rupees but does not exceed ten crore rupees;

(b) In the case of the enterprises engaged in providing or rendering of services, as--

(i) A micro enterprise, where the investment in equipment does not exceed ten lakh rupees;

(ii) A small enterprise, where the investment in equipment is more than ten lakh rupees but does not exceed two crore rupees; or

(iii) a medium enterprise, where the investment in equipment is more than two crore rupees but does not exceed five crore rupees.

Explanation 1. --For the removal of doubts, it is hereby clarified that in calculating the investment in plant and machinery, the cost of pollution control, research and development, industrial safety devices and such other items as may be specified, by notification, shall be excluded.”

Keeping in mind the issues stated above, the researchers have focused on the following factors and practices prevalent in SME sector:

a. Types of organization;

b. Number of years the organization is in operation and its management structure;

c. Issues relating to the risk management and their level of awareness;

d. Accounting practice adopted by the sector in general;

e. Their comfort levels towards the existing legal compliance requirements;

f. Their exposure towards Information Technology.

\subsection{Approach Adopted}

The following approach has been adopted for the study:

a. Literature has been reviewed to accentuate conceptual development of the need for corporate governance in Small and Medium Scale Enterprise sector

b. Corporate Governance ‘tool kits’ developed by some countries have been referred.

c. Proprietary database of SMEs has been purchased to identify the SMEs operating in the various regions. Subsequent to identification of nearly 30000 firms, a random sampling of 5000 SME's has been done from the identified zones, keeping in mind the representativeness of the sample from different sector. 
d. The field researchers approached the firms, personally or through telephone or electronic communication. Out of those contacted, only 2211 [Two thousand two hundred and eleven firms] responded.

e. A structured questionnaire has been prepared with an approximate number of 27 questions. Enumerators have been trained and briefed about the object and purpose of the study and the questions, in particular. The questionnaires were administered to the Office bearers of the firms for the purpose of eliciting answers. To facilitate the receipt of quick and unbiased data from the remote pockets of the country, web enabled questionnaire has been circulated electronically after telephonic conversation with the targets.

f. Classification has been done based on organization structure, capital deployment and employed work force.

g. After collection of the data it had been classified and coded. Software package has been used to analyze the responses of the target.

\subsection{Limitation of the Study}

The study has faced certain limitations in its approach and collection of primary data:

1. There has been poor participation from the part of the targets. Encouraging participation has been seen from the western part of the country, but the same is not true for the southern, eastern and northeastern part of the country. Participation from northern and central India has been average.

2. Firms are skeptical about information sharing.

3. Sizeable number of SME's is situated in the deep pockets of the country which were unapproachable; so, the study has been largely confined to the SME's situated in semi-urban and urban area.

4. Some questions have remained unanswered by the enterprises, mainly due to their reluctance to share information. 


\title{
Al Macrothink
}

\section{Analysis of Primary Survey}

Primary data has been collected based on the schedule in the Annexure I. The preamble of the schedule reads as 'The objective of the study lies in generation of knowledge base about SMEs and suggesting industry friendly corporate governance norms for small and medium enterprises. The study specifically investigates the issues of implementation of corporate governance norms in this sector.'

\section{Table I}

\section{Types of Business Form in this Sector}
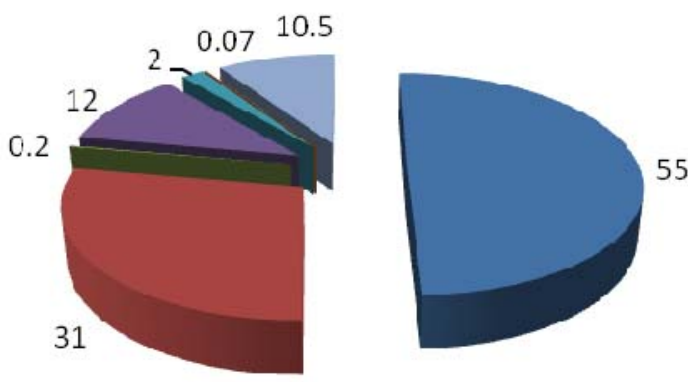

\author{
- Proprietorship \\ - Partnership \\ Co-operative society \\ - Private company \\ - Public company \\ Public listed company \\ No Answer
}

As may be seen above, out of the total number of surveyed firms, proprietorships and partnerships constituted 55\% and 31\% respectively. Therefore, $86 \%$ of the total firms belong to the informal sector. Whereas Private Company, Public Unlisted and Listed Company and Co-operative Firms occupy $12 \%, 2 \& 0.07 \%$ and $0.2 \%$ of business forms respectively in the formal sector.

\section{Table II}

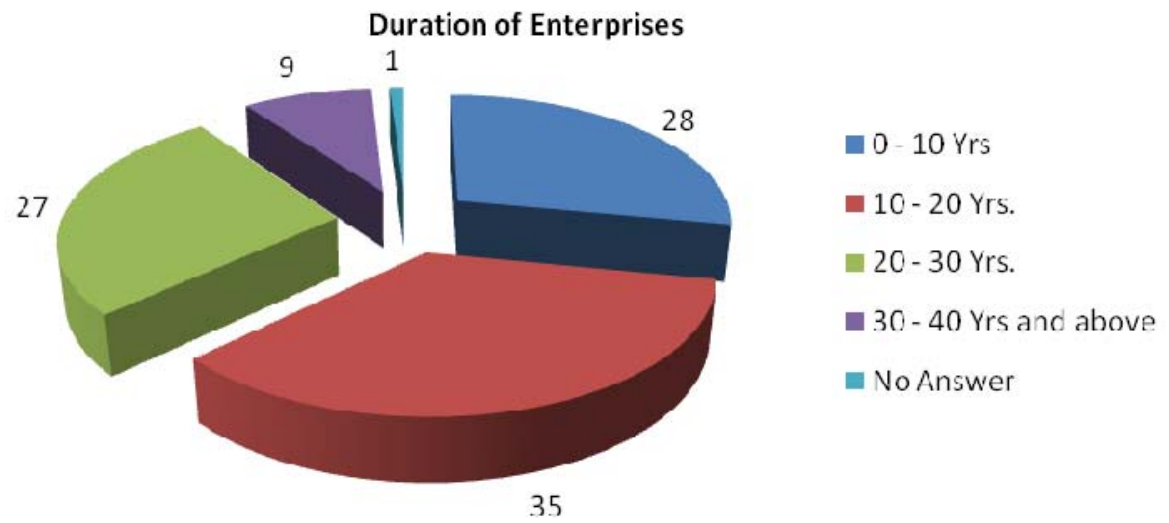

Table II represents that $63 \%$ of the enterprises are incorporated during last 20 years. Almost $27 \%$ are incorporated within 30 years, whereas $9 \%$ of the firms exist more than 30 years. It indicates that economic liberalization encouraged more enterprises to incorporate in this sector. 


\section{Table III}

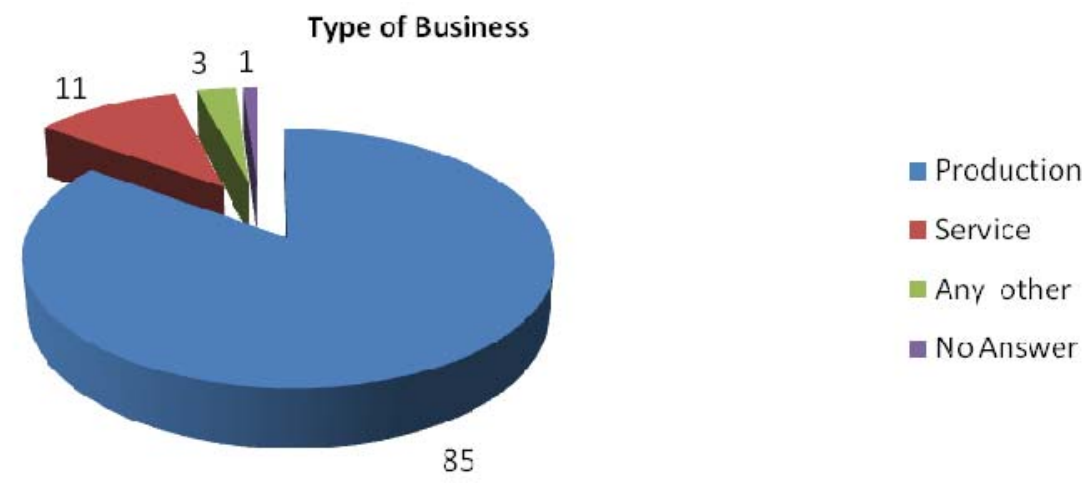

Table III shows that out of the total enterprises surveyed, $85 \%$ of the enterprises belong to the production sector which represent the largest in the segment, whereas only $14 \%$ belong to the service sector.

\subsection{Capital of Enterprises}

Initial Capital of the enterprises is provided in the tables:-Table IV is representative of enterprises involved in production and Table V of enterprises involved in the services.

\section{Table IV}

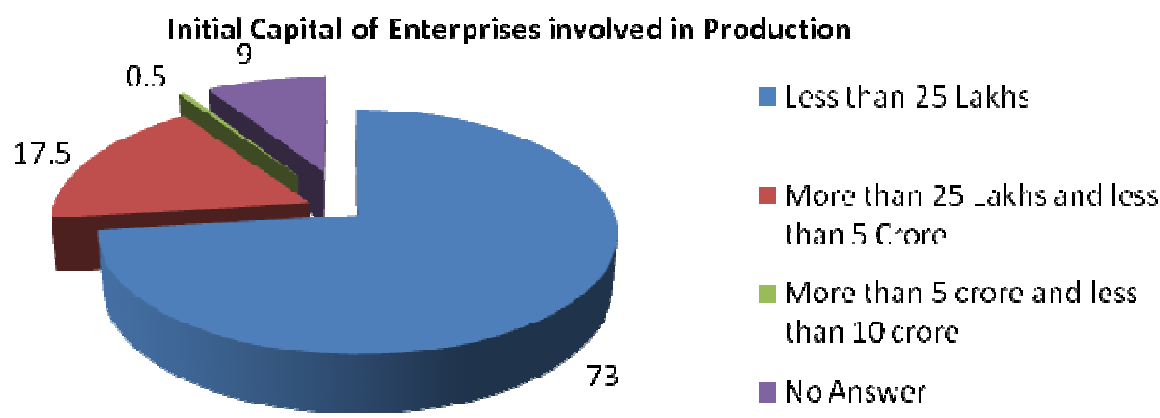

Table IV shows that $73 \%$ of the enterprises involved in production sector having initial capital less than 25 Lakhs, so belong to micro enterprise; $17.5 \%$ of enterprises having more than 25 Lakh of capital constitute small enterprise; and only $0.5 \%$ enterprises are medium enterprise having more than five crore capital. $9 \%$ of the enterprises have not provided any data. 


\section{Table V}

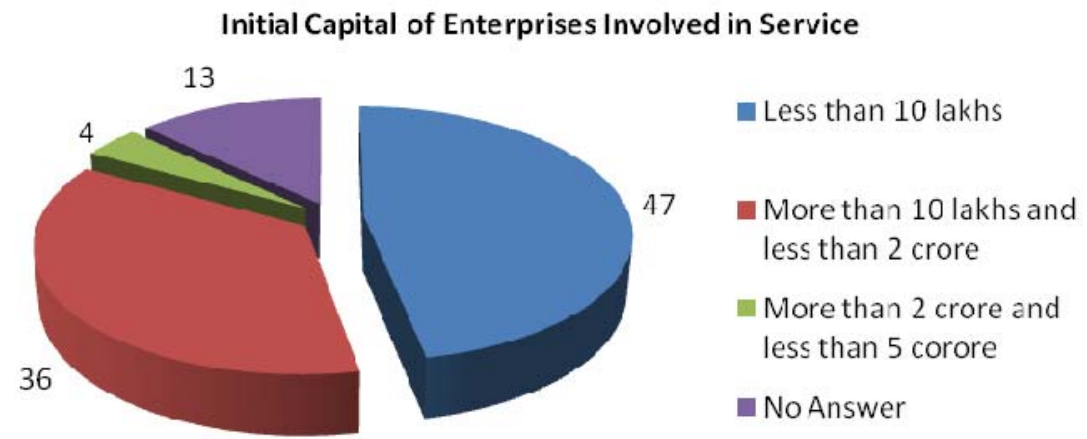

Table V shows that $47 \%$ of the enterprises involved in service sector having initial capital of 10 Lakh belong to micro enterprise; 36\% of the enterprises having more than 10 Lakh of capital constitute small enterprise; and only 4\% enterprises are medium enterprises having more than 2 crore capital. A substantial number of $13 \%$ of the enterprises abstained from providing any data.

Tables VI and VII represent the present capital of the enterprises in the production and service sector.

\section{Table VI}

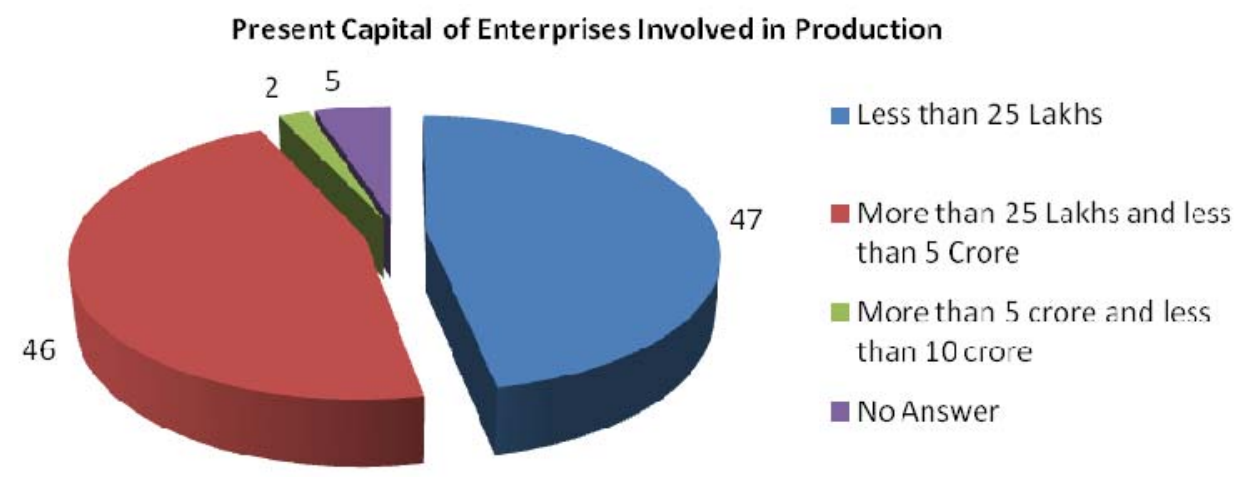

Table VI shows that there is a capital growth in the production sector. $47 \%$ of the enterprises have less than 25 Lakh present capital, in contrast to 73\% enterprises having less than 25 Lakh at the beginning of the business. The trend is similar in small sector; therewere $17.5 \%$ enterprises having more than 25 Lakh which has increased to $46 \%$ over the time. The percentage of medium scale enterprises increased from $0.5 \%$ to $2 \%$. 


\section{Table VII}

\section{Present Capital of Enterprises Involved in Service}

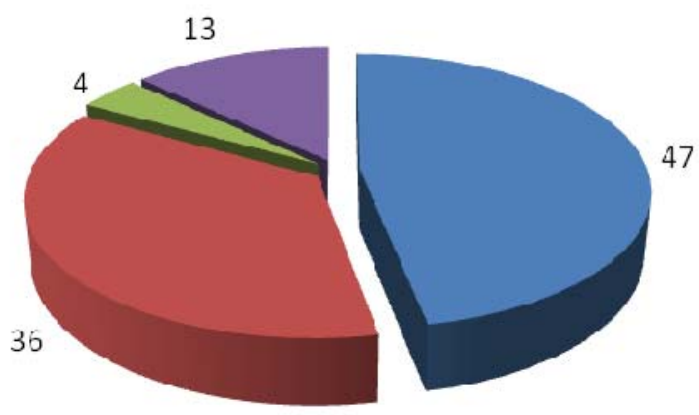

- Less than 10 lakhs

- More than 10 lakhs and less than 2 crore

More than 2 crore and less than 5 corore

No Answer

Table VII shows an interesting result. The figure represents that there has hardly been any growth in this sector in comparison to its initial capital.

Table VIII

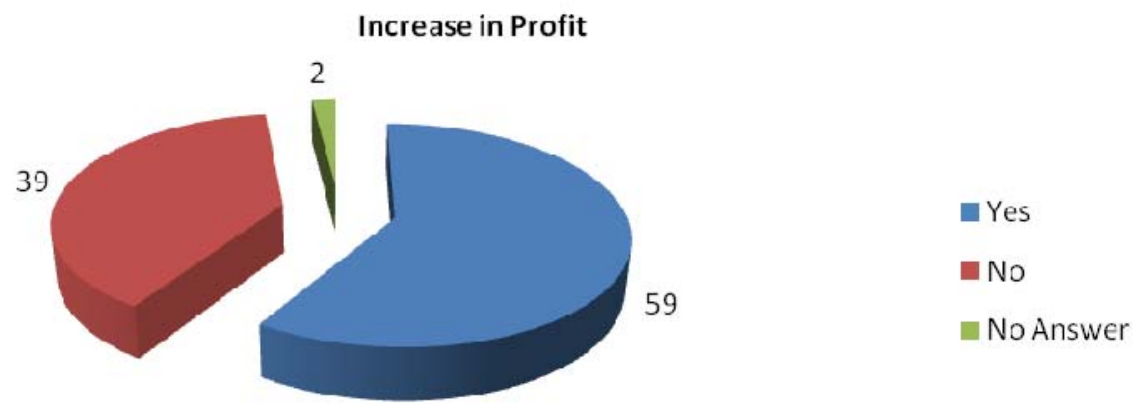

Table VIII reveals that $59 \%$ of the enterprises earned profit over the years.39\% enterprises claimed losses, whereas $2 \%$ of the enterprises abstained from answering this question. 
Table IX

Change in Business Form

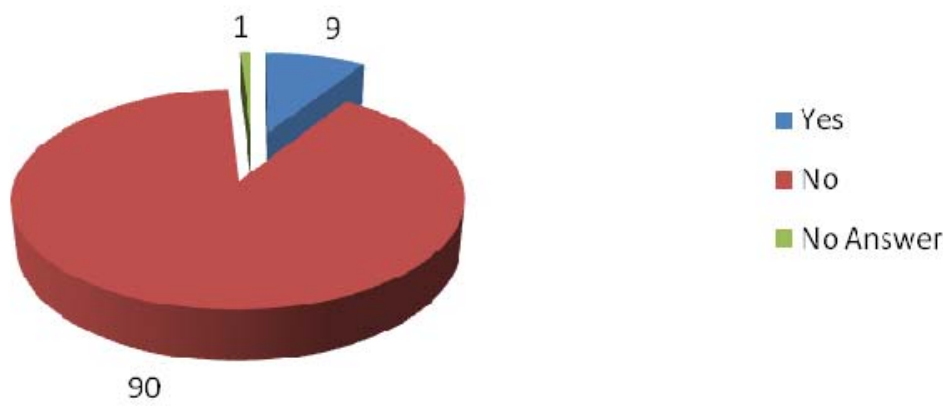

Table IX shows that $90 \%$ of the enterprises haven't change its business form, even though there is a substantial growth in the capital of the enterprises. Only $9 \%$ of the enterprises have converted to the informal sector, mainly to private company. It is also the internal growth indicator of the enterprises. Even though the enterprises have sustained growth over the period, it has been unable to achieve substantial internal growth for transformation.

The enterprise started as private company but converted to public company after six years. Aurangabad, Murshidabad

\subsection{Knowledge of Risk Management and Manpower}

In matters of risk management, the following aspects have been established.

Table X

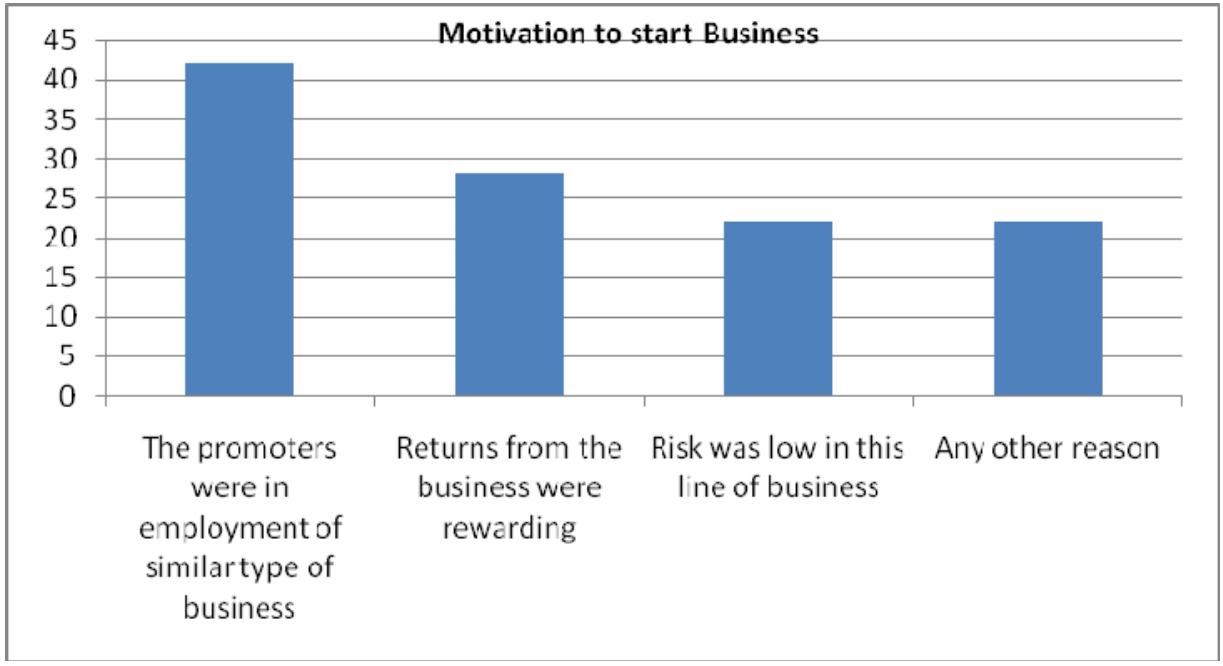

The researchers were interested to know what factors motivated the first promoter to start the enterprise. The objective of the question was to understand whether the first promoter/s was 


\section{Macrothink}

aware about business risks in different stages. The question was open for multiple responses. More than $40 \%$ of the respondent replied that they were employed in similar business, whereas more than $25 \%$ and $20 \%$ of the entrepreneurs replied that business return was high and risk was low. Another $20 \%$ of the entrepreneurs said the family was involved in other type of businesses and they have diversified to the present business or the raw material in the input market was easily available, less capital intensity, easy availability of skilled labour, less labour dependency, entrepreneur was an engineer or trained in similar vocation.

To understand the existing management structures of the enterprise and its professional characteristics, the researchers posed several queries. The same are as below.

\section{Table XI}

Separation of Management from Ownership

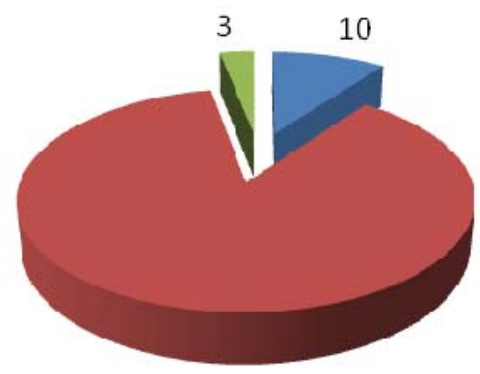

Yes

No

No Answer

87

On question of separation of ownership and management of enterprise,87\% said there is no separation between the ownership and management, whereas $10 \%$ reported that there is difference between the management and ownership in the enterprise. $3 \%$ abstained from responding.

'The number of members in the family have increased which lead to dispute in the business.' Mirzapur 
Table XII
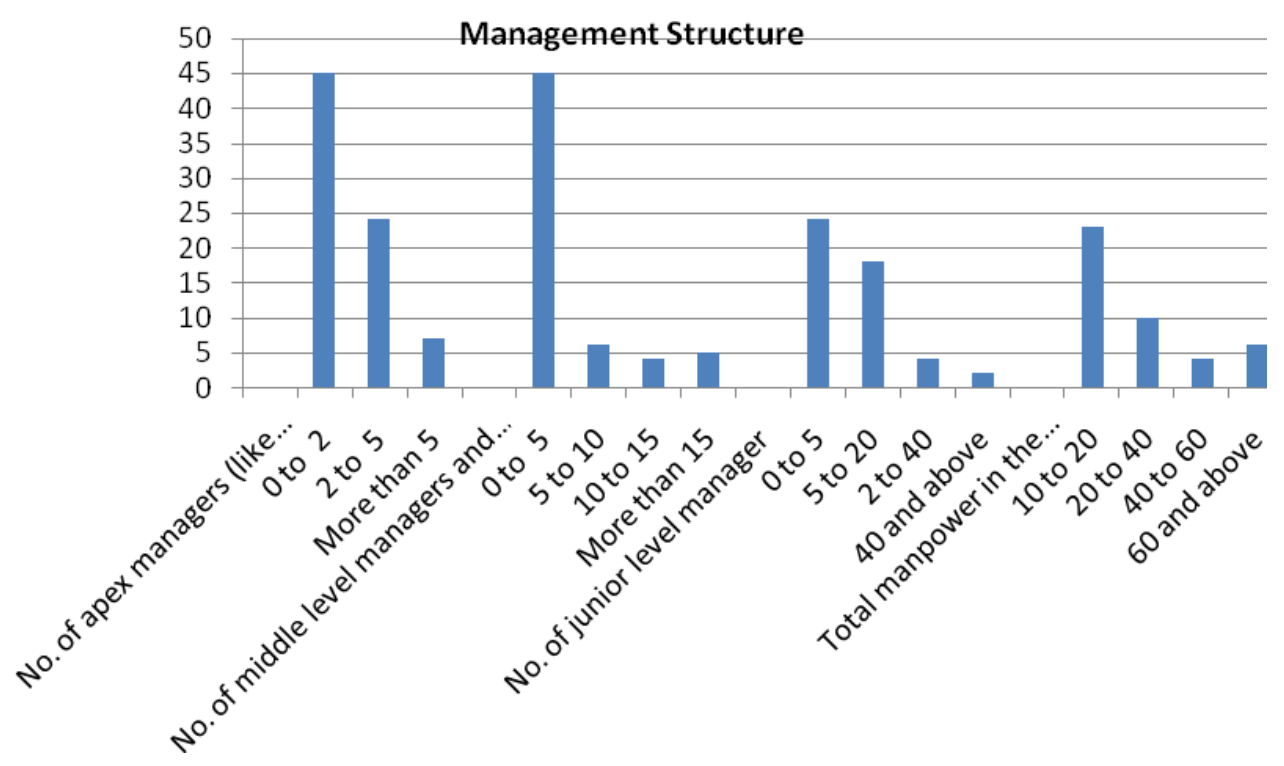

$23 \%$ of the enterprises told that they have lesser than twenty manpower. $10 \%$ enterprises have below than forty manpower, whereas, below $5 \%$ of enterprises have less than sixty man power and little more than $5 \%$ of the enterprises more than sixty man power.

Percentage of Apex Manager [Proprietor, Partner and Director etc.] in the enterprise amongst the total manpower

In $45 \%$ of the enterprises, apex management comprises of less than two persons. In less than $25 \%$ of the enterprises, apex management comprises of two to five persons and only $7 \%$ of enterprises have more than five persons in the apex management.

\section{Percentage of Middle Manager in the enterprise amongst the total manpower}

$45 \%$ of the enterprises have less than five persons in the middle management. $6 \%$ and $4 \%$ of the enterprises have less than ten persons and more than ten persons but less than fifteen persons. Only 5\% of the enterprises have more than fifteen persons.

\section{Percentage of Lower Manager in the enterprise amongst the total manpower}

$24 \%$ of the enterprises have less than five persons in the junior management level whereas $18 \%$ enterprises have more than five persons and less than twenty persons. Only in $2 \%$ of enterprises there are more than forty persons in the junior level. 
Table XIII

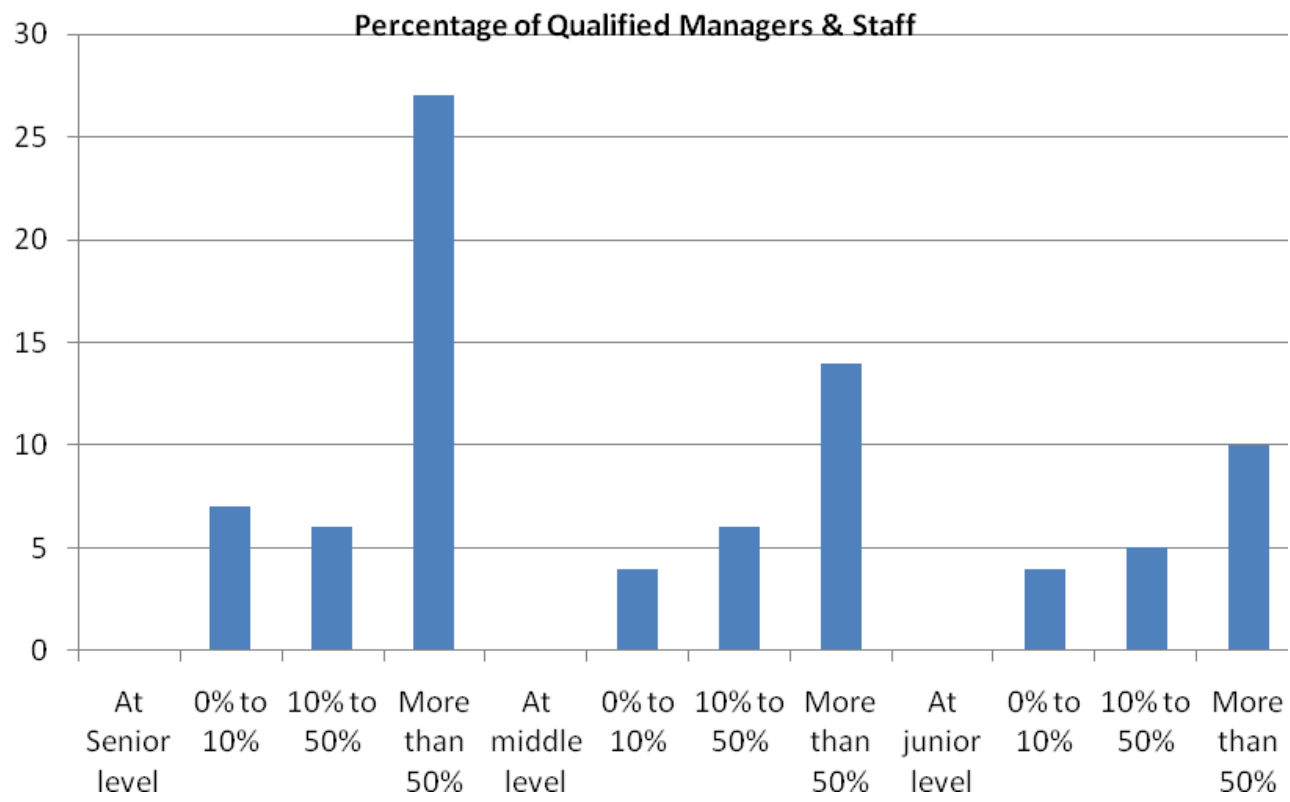

Interestingly, $68 \%$ of the enterprises said that more that $27 \%$ of the higher management is professionally trained or they possess technical qualification in the relevant area. But only $18 \%$ of the enterprises reported that less than $7 \%$ of the managers in the higher levels are professionally qualified.

In contrast to the above, $58 \%$ of the enterprises projected that they have more than $14 \%$ of the people professionally qualified in the middle management level; whereas $24 \%$ of the enterprises only said that they have less than $4 \%$ of the people professionally qualified.

Percentage of professionals at Junior Level also represents a similar picture as it is in middle management level.

Table XIV

Awareness of Employee of Organisation Activity

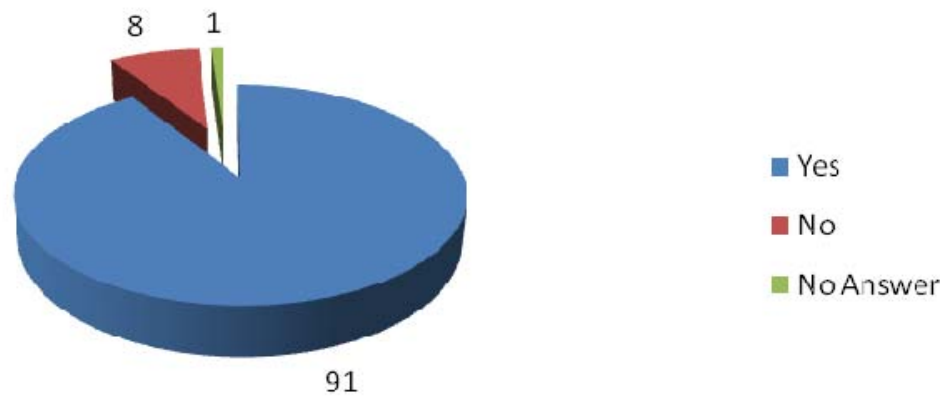




\section{Macrothink}

Journal of Public Administration and Governance

ISSN 2161-7104

2011, Vol. 1, No. 2

$91 \%$ of the enterprises said that their employees are aware of the enterprise activities. $8 \%$ of the enterprises said that the employees are not aware, reason being that either they are not educated or management is not interested to tell them.

\section{Table XV}

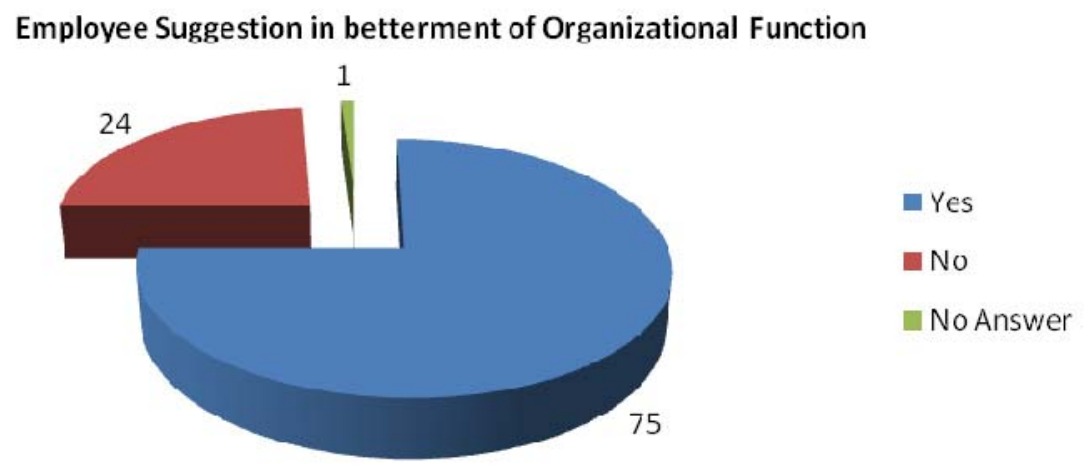

Interestingly, $75 \%$ of the enterprise said that the management considers suggestions of the employees for the better functioning of the organization.

\section{'The people here are not educated so they do not have knowledge of business'. Mirzapur}

\section{Table XVI}

Employees Participation in Professional Training Program

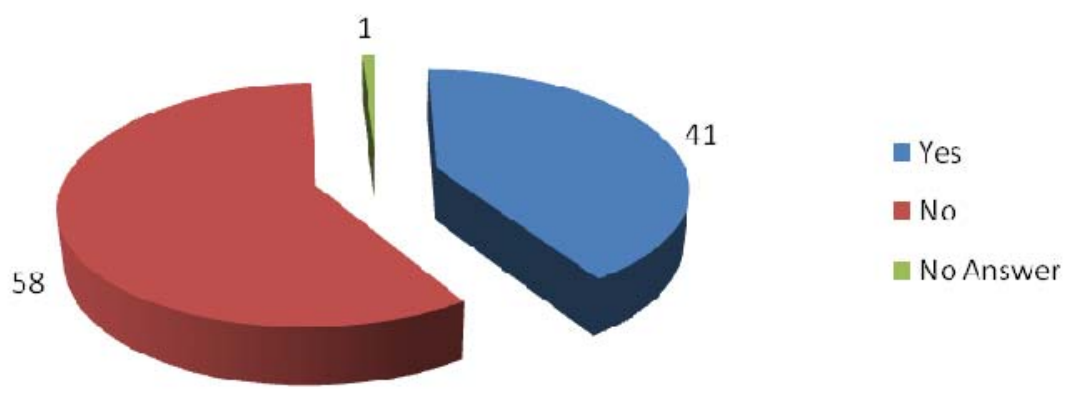

On the question of how many employees go through regular training program for professional development and advancement in their respective trade, $58 \%$ of the enterprises answered in the affirmative while another $41 \%$ in the negative.

'All technical institutes must have Training Programmes for employees of SME’s .' Ambala 
Table XVII

\section{Source of motivation for undergoing Training by Employee}

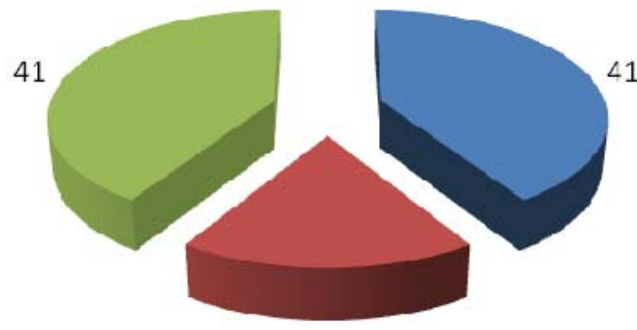

41 Insisted by the enterprise

- Voluntary

NoAnswer

Out of the $58 \%$ of the enterprises where employees undergo regular training, it was found that $41 \%$ enterprises insisted employees to undergo the regular training programs in the respective trade; whereas, in $18 \%$ of the enterprises, employees' training is merely voluntary.

\subsection{Financial Disclosure and Enterprise Audit}

Disclosure on the issues of auditing practice and financial disclosures of the enterprises have revealed the following facts.

Table XVIII

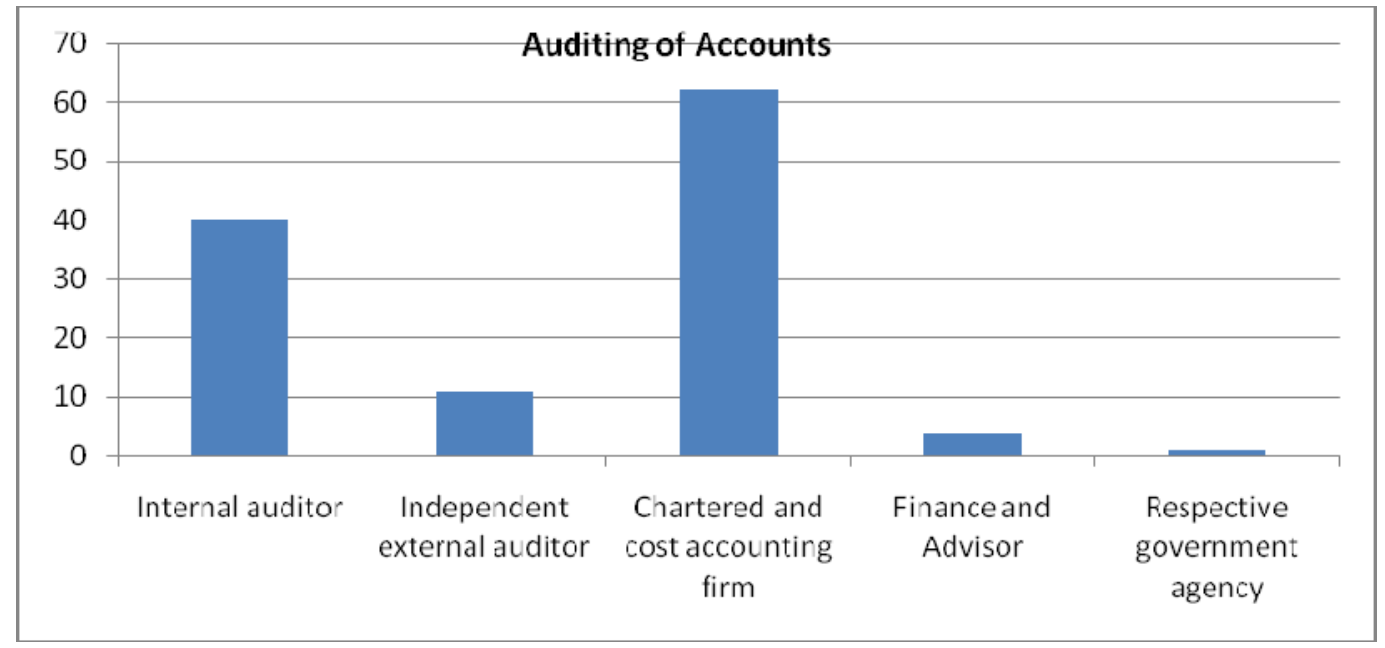

The question was posed to enterprises 'who audits the accounts of the enterprises'? It was expected that many enterprises would respond to the multiple answers. The objective of the question was to know whether the enterprises appoint professional auditors to conduct the audit of the enterprises and whether they follow any accounting procedure. It was found that majority responded in favour of professional auditors like 'Chartered and Cost accounting 


\section{MInstitute Mach $^{m}$}

firm' [62\% of the enterprises], Independent External Auditor [40\% of the enterprises]; another substantial number of the enterprise said it is done by internal employees like 'Internal auditor' [ $40 \%$ of the enterprise], and about $4 \%$ by 'Finance and Account Advisor'.

\section{Table XVIV}

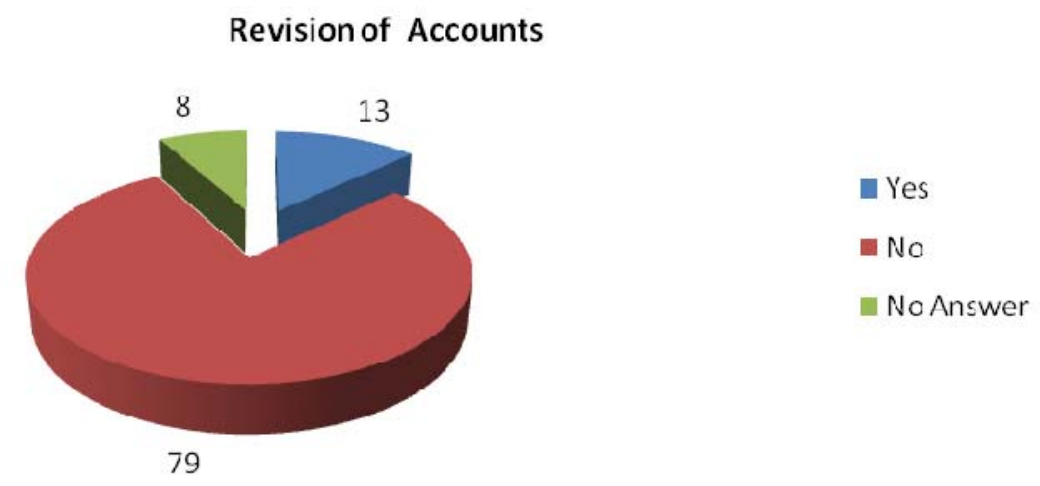

The enterprises were asked whether they revise the accounts before they submit to the respective regulator- to understand the level of professionalism they maintain about account preparations. $79 \%$ of the enterprise said they don't revise the accounts where as $13 \%$ enterprise confessed that they revise the accounts. Some of them have reasoned that this is to rectify the mistake in the account statement while others are silent on the point.

\section{Table XVV}

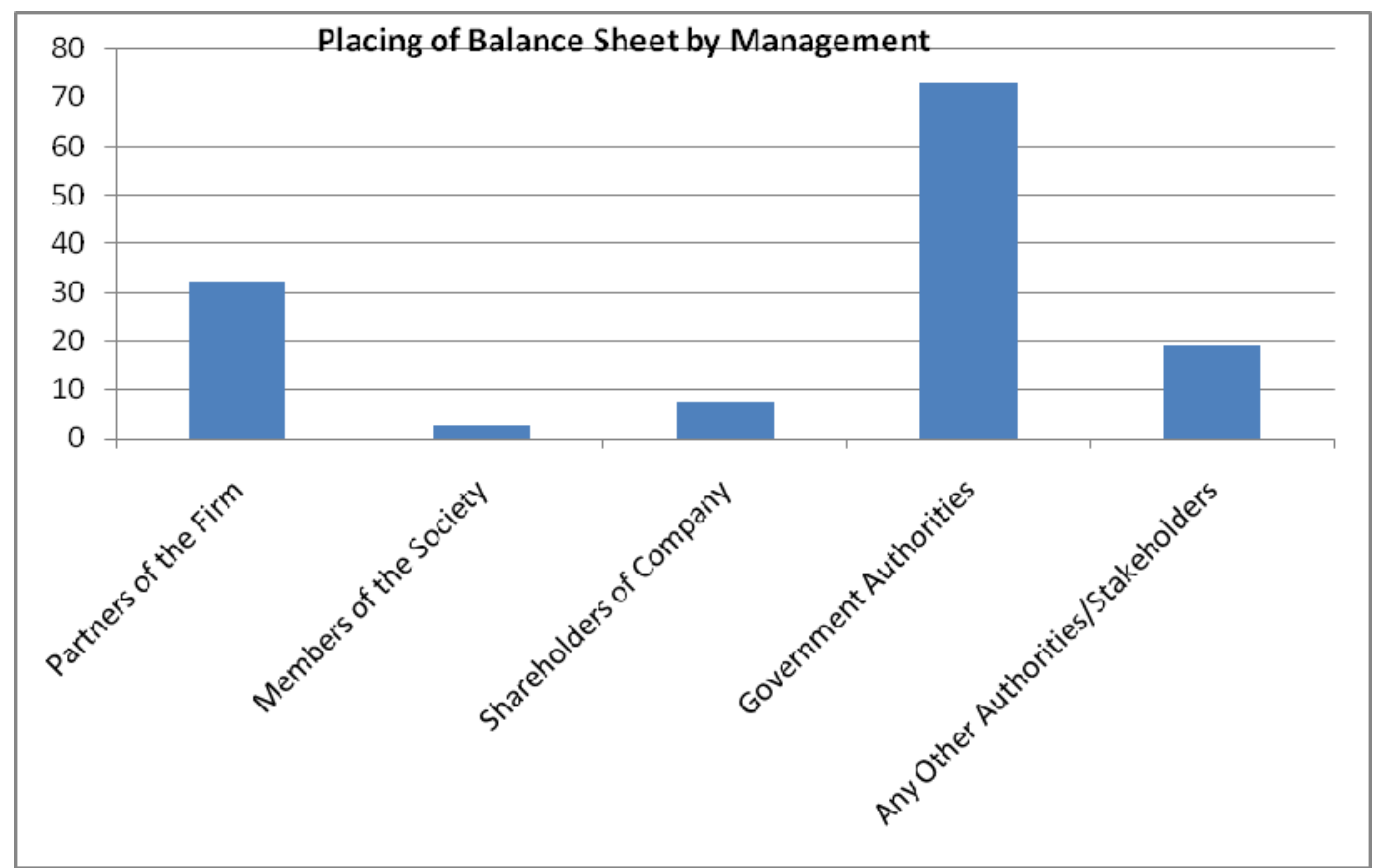




\section{Macrothink}

Journal of Public Administration and Governance

ISSN 2161-7104

2011, Vol. 1, No. 2

The researchers were looking for multiple answers for this question. On enquiry to enterprises as to whom the management place the accounts, $73 \%$ said Government Authorities like Income tax, DIC, Registrar of Company etc.32\% answered business partners and $19 \%$ before other agency like banks etc.

\section{Table XVVI}

\section{Audited Profit of the Enterprise}
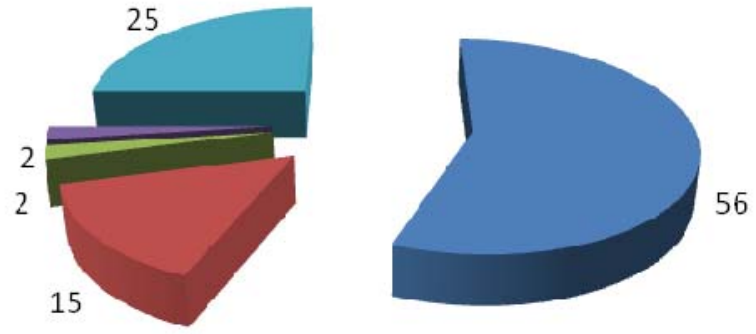

$$
\begin{aligned}
& \text { Less than } 10 \text { Lakhs } \\
& \text { Less than } 50 \text { lakhs } \\
& \text { Less than } 1 \text { crore } \\
& \text { More than } 1 \text { crore } \\
& \text { NoAnswer }
\end{aligned}
$$

The table shows that $56 \%$ of the enterprises have less than ten lakhs audited profit whereas about 20\% enterprises have less than Rupees 50 lakhs of audited profit. 25\%, a significant number, of enterprises abstained from responding to this question.

\subsection{Regulatory Compliance}

On the issue of regulatory compliance, enterprises have given the following responses.

\section{Table XVVII}

Regulatory Barriers during Initiation of Business
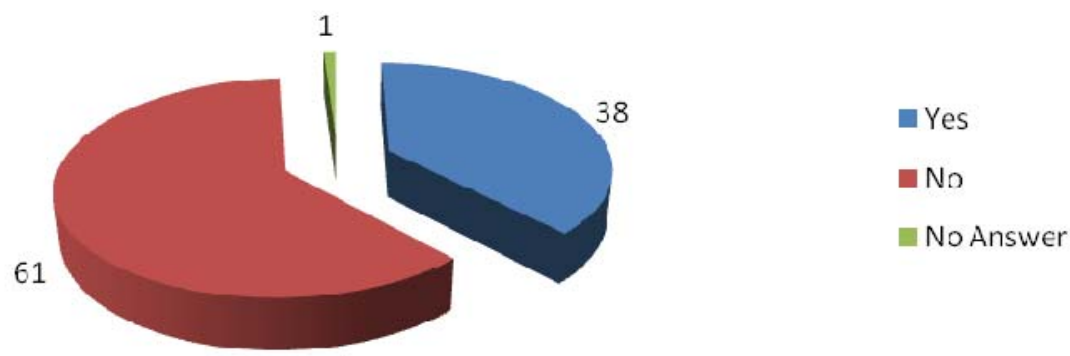


\section{Macrothink}

Journal of Public Administration and Governance

ISSN 2161-7104

2011, Vol. 1, No. 2

On the issue of regulatory barriers at the time of initiation of business,38\% of enterprises voted in the affirmative, whereas $61 \%$, that is majority of enterprises, said that they have not faced any difficulty. On the issue of multiple regulatory permissions, majority of the enterprises gave an affirmative answer. $1 \%$ abstained from answering the question.

'The State Government takes prolonged time for sanctioning the project’ Dibrugarh

'A lot of permissions are needed to start up the business'. Sultanpur

'Regulations regarding water \& air pollution should be according to business requirement.' Panipath

'Government should ensure peaceful business environment for the Industry’ Panipath

'There should be single window system regarding all regulatory systems. Solan

'Government should facilitate industrial Infrastructure'. Paewanoo

'There are several types of permission needed. Infact, we also do not know how many types of permission are

required. Some or the other govt. agencies come and say that we need to register with them'. Balasore

“There should be one window solution for licenses.” Malda

“ Too many regulation in the tobacco industry” Aurangabad, Murshidabad 


\section{Table XVVIII}
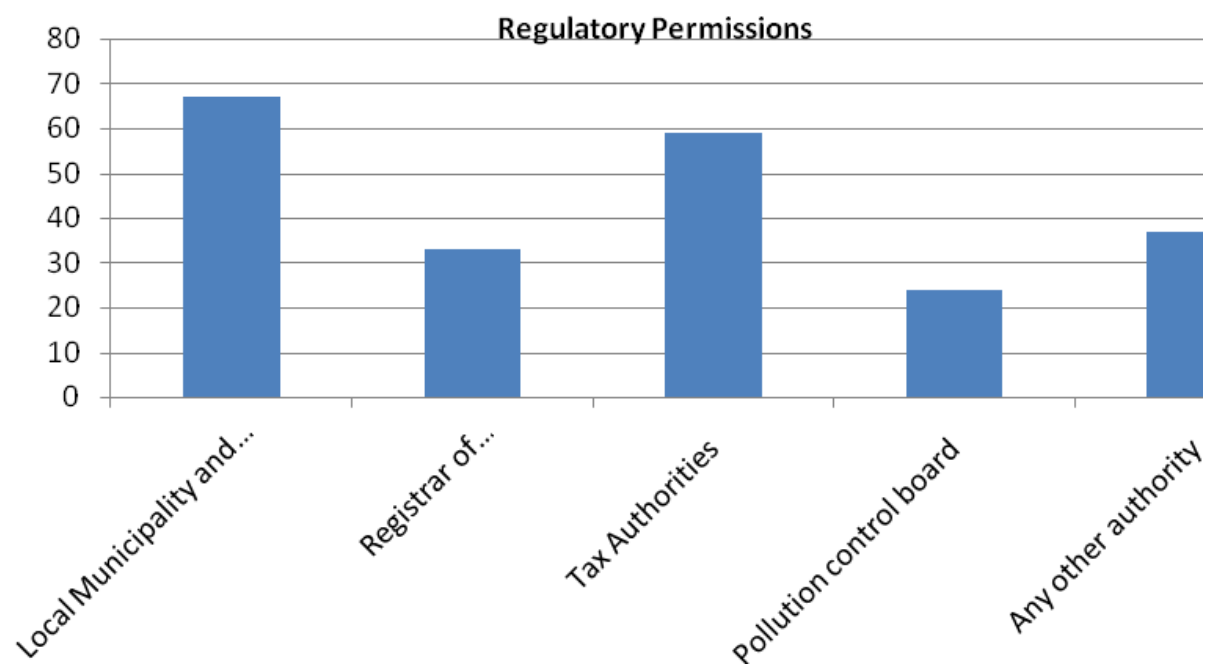

The enterprises were questioned regarding the authorities whose permissions were required, in general, to initiate the business. There have been some multiple answers in this category. $67 \%$ enterprises said they have to take permission from Local authorities like Municipality and Panchayat; 59\% enterprises said that they have to take required permission from the Tax Authorities whereas 37\% enterprises said other authorities like DIC, Bank etc.

\section{Table XVIX}

\section{Annual Cost of Regulatory Compliance}

11

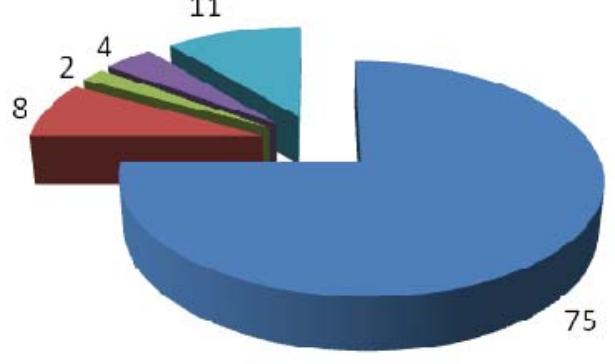

Less than 5 Lakhs

More than 5 Lakhs and less than 20 Lakns

More than 20 Lakhs and less than 40 Lakhs

- More than 40 Lakhs

No Answer

As regards annual cost of regulatory compliance, $75 \%$ of the enterprises said that they spend less than Five Lakh, 8\% of the enterprises said it is in between 5 Lakh to 20 Lakh, whereas $2 \%$ and $4 \%$ of the enterprises said that it is in between 20 Lakh to 40 Lakh and more than 40 Lakh respectively. It seems that the compliance cost is higher as compared to audited profit 
posted by them in Table XVVI.

\section{Table XX}

\section{Information on Different Promotional Schemes}
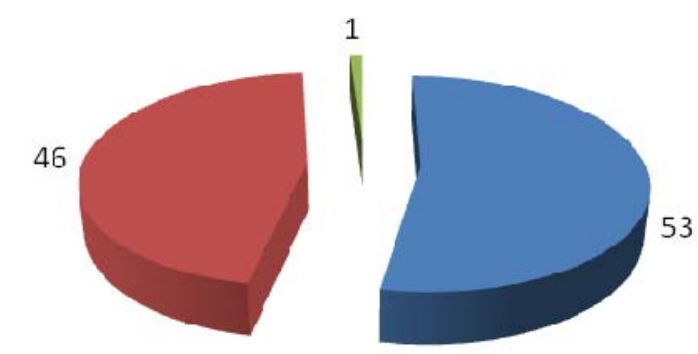

- YeS

No

No Answer

On the question of accessibility of the different promotional schemes of the SME's, 53\% of the enterprises said that those are timely available to them, but there are substantial number of enterprises, almost $46 \%$, who said that those are not available.

\footnotetext{
'There should be transparency in Govt. action and plans. Govt. should take the industry in confidence.' Nagpur

'Reduce the interference of various government agencies inthe functioning of the government schemes, passing of the benefits to the real beneficiaries' Bangalore

'There should be free and fair market regulators and govt. facilities without any personal interest of officials. Almost everyone knows of problems due to officials of government but no one is resolving the problem. Some regulators also say that money has to come through industry and go to the political funds.' Indore

'Need more practical and proactive approach from bank and government agencies. This will go a long way to make our enterprises to grow from small to medium level in the near future'. Chennai

'Government must bring simple system towards sanctioning the licences and bank must come forward openly to finance business keeping confidence over SME's and also no political interference should be there.Allow the authority to take decision as per merits of the company/business establishment.' Madurai

'All government departments should be well-systemized\&non corrupt. This will help industries to grow more faster'. Bhavnagar

'Due to the non existence of Handicrafts Directorate in the state of Assam, the grievances of this sector is not properly conveyed to the government.the major difficulties are; 1) Lack of organizational supply of raw material 2) Poor infrastructure 3) Poor connectivity 4) Lack of adequate finance'. Slichar

'Most of the promotional schemes are only notified to the depts./financial institutions. This information is not passed on to any individual companies.' Chennai
} 


\title{
Macrothink \\ Journal of Public Administration and Governance \\ ISSN 2161-7104 \\ 2011, Vol. 1, No. 2
}

\subsection{Exposure to information Technology}

The researchers were interested to know the exposure of the sector to information technology since, compliance to corporate governance may be enhanced through e-governance.

\section{Table XXI}

Number of Computer per Enterprise

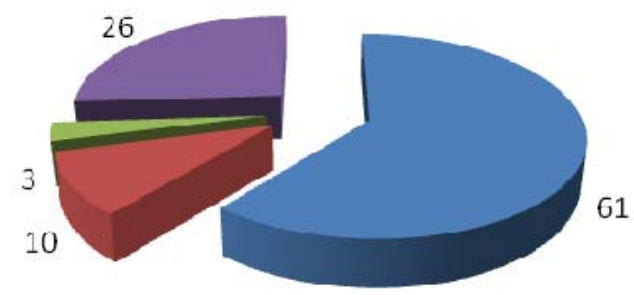

\author{
- Less than 5 \\ 5 to 20 \\ 20 and above \\ No answer
}

On the question of number of computers the enterprise use, it is found that $61 \%$ of the enterprises have computers, not exceeding five and about $10 \%$ have a maximum of 20 computers. Almost $26 \%$ of the enterprises have preferred not to answer the question, maybe for the reason that they are not well equipped technologically.

Table XXII

Filing of Returns Online
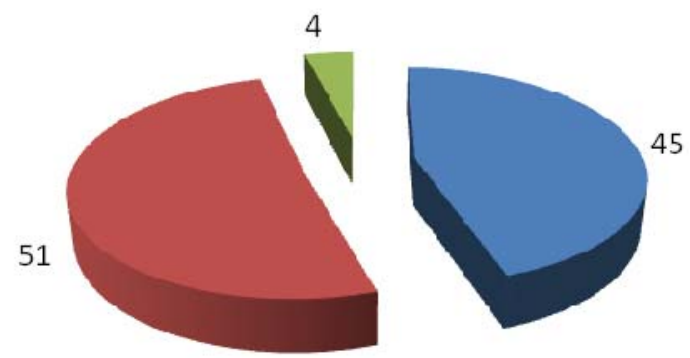

$$
\begin{aligned}
& \text { Yes } \\
& \text { No } \\
& \text { No Answer }
\end{aligned}
$$

As regards the number of enterprises who file returns online and receive schemes through similar facility, almost $45 \%$ of the enterprises answered in the affirmativewhile $51 \%$ of the enterprises have given the answer in negative. 


\section{Table XXIII}

\section{Preference for Online Enquiry and Filing Facilities}

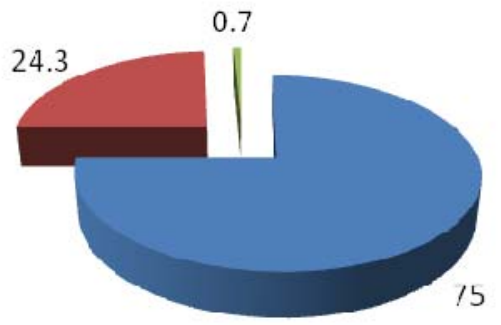

$$
\begin{aligned}
& \text { Yes } \\
& \text { No } \\
& \text { No Answer }
\end{aligned}
$$

Tables XXIII shows $75 \%$ of the enterprises have expressed their interest to file annual There should be workshops and demonstrations on online filing. WB VAT has not held any such workshop and demonstrations. Midnapur

regulatory compliances online, while another 24\% have expressed otherwise.

\section{Findings of the Primary Survey}

a. Eighty-six present of total business form belong to the informal sector, i.e., Proprietorship and Partnership.

b. Economic liberalization has encouraged many enterprises to incorporate in this sector. The survey established that substantial number of enterprises have sustained more than twenty years in the market.

c. Eighty-five percent of the enterprises in this sector belong to productions. Some of the enterprises provide service to different production units or are franchise of the big company. The number of service enterprises is very less as compared to production enterprises. In attempting to find out the reason, many proprietors replied that non-availability of bank loans, business risks etc. act as de-motivating factors.

d. It has been found that over the years enterprises have increased their business capital. That gives the impression that the enterprises are making profits and in sustainable business process. The majority of the enterprises have also acknowledged that there has been increase in profit over the years.

e. Majority of the promoters started their business as proprietor or partnership firm and most of them were employed in similar type of business. Interestingly, it has also been found that though there was increase in profit and growth in capital, the entrepreneurs have chosen not to convert their business from proprietorship or partnership to incorporate company. The promoters/proprietors of first generations were well aware 
of the business risks. Awareness level regarding the benefits of converting business in to a company is however low amongst the entrepreneurs. It is well established notion now that institutionalization of business in the form of a company minimizes the inherent business risks. On the contrary, there is fear of more regulatory hassles and increase in cost of regulatory compliance.

f. Proprietors ordinarily are in the Management of the enterprises. Only ten percent of the enterprises said that the owners of the enterprises are not involved in day-to-day management. Therefore, there are very few enterprises with separate management ownership structure.

g. The apex and middle management of the enterprises are manned by comparative less number of people. However, a substantial number of enterprises have said that their apex managements are professionally qualified. This is an important finding in the study. Decline trends are found in the middle and lower management regarding professional qualifications as compared to apex management.

h. On the issue of stakeholder awareness and participation in the business, almost ninety-one percent enterprises informed that the stakeholders are aware about the activities of the firms and seventy-five percent welcomed suggestions of their employees regarding improvement of organizational management and firm activities. The concept of stakeholder participation in organizational management is one of the well-accepted principles of good corporate governance where this sector does fairly well.

i. Continuous capacity building and professional development of employees is one of the key elements of sustainable business development and also an integral principle of corporate governance. Fifty-one percent of the enterprises replied that their employees undergo regular training programs. Out of that, it nearly forty-one percent enterprises send and sponsor the training programs of their employees.

j. The accounts of the enterprises are generally audited by persons trained in accounts and audit. It is found that for sixty-two percent of the enterprises, accounts are audited by Chartered and Cost Accounting firm. For other enterprises, the internal auditors carry forward this job. So, there is evidence of adopting the modern accounting practices within the enterprises. Regarding the disclosure of accounts, the firms take the traditional approach. Disclosure is only to those who are statutorily prescribed like the other partners in the firm, members of the society, shareholders or Government authority or banker.

k. In regulatory compliances, it has been found that the enterprises are required to go through multiple regulators, though majority of enterprises said that initial regulatory compliance at the time of starting of business is not big hassle. But there has been opinion expressed in the survey that multi-regulatory compliance creates problems at times. The cost of regulatory compliance seems to be quite high when compared to the audited profit of the enterprises. 
1. The exposure of SME to information technologies is quite impressive. About forty-one percent of the enterprises file their regulatory returns online. Seventy-five percent of the enterprises are interested to get online promotional schemes and file regulatory returns if provided only. So, there is a fair scope to effectively use e-governance for effective compliance of corporate - governance.

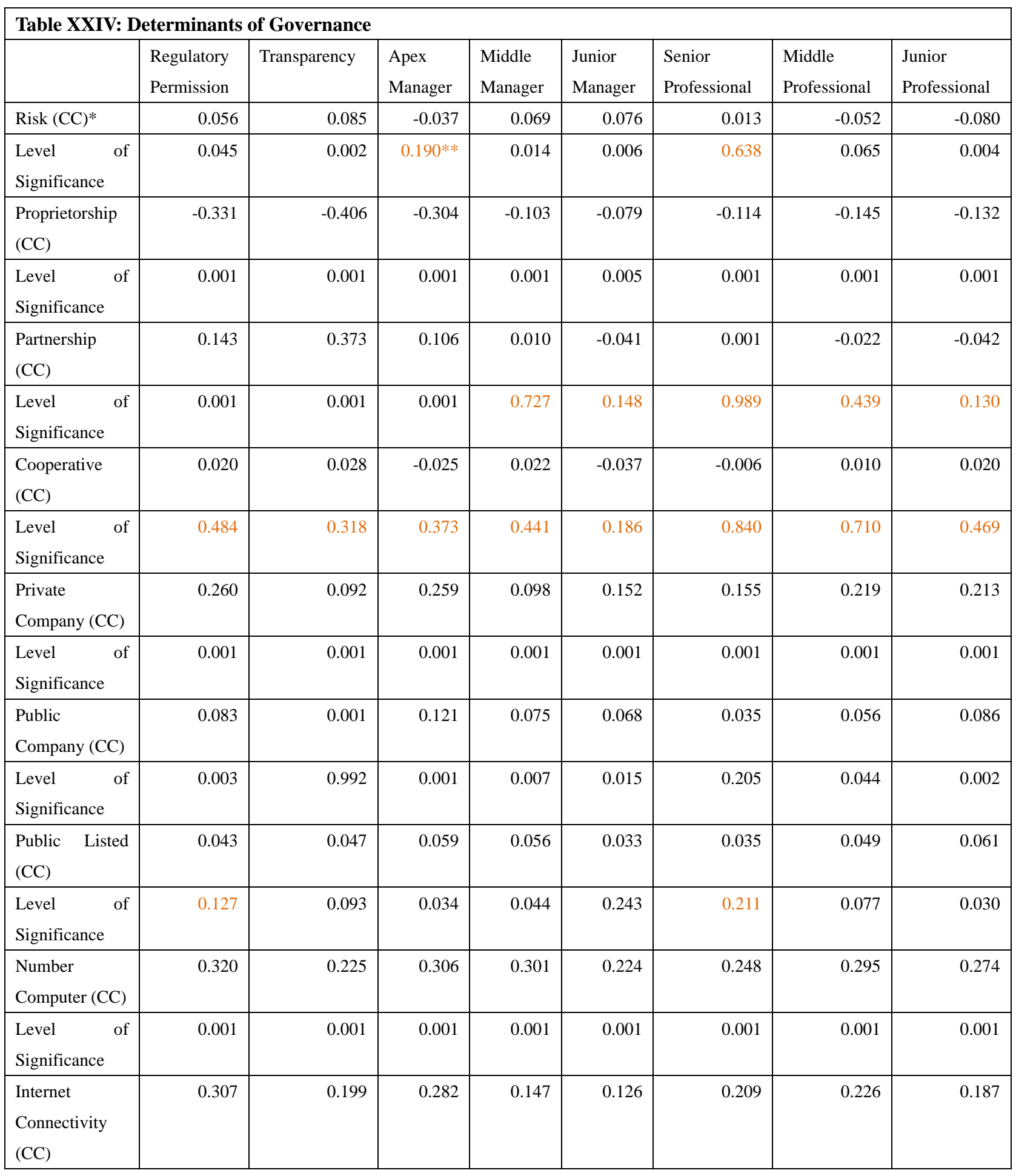




\begin{tabular}{|l|r|r|r|r|r|r|r|r|}
\hline $\begin{array}{l}\text { Level of } \\
\text { Significance }\end{array}$ & 0.001 & 0.001 & 0.001 & 0.001 & 0.001 & 0.001 & 0.001 & 0.001 \\
\hline $\begin{array}{l}\text { Capital } \\
\text { Structure (CC) }\end{array}$ & 0.020 & 0.017 & -0.036 & -0.024 & -0.020 & -0.023 & -0.015 & -0.013 \\
\hline $\begin{array}{l}\text { Level of } \\
\text { Significance }\end{array}$ & 0.470 & 0.554 & 0.203 & 0.390 & 0.468 & 0.421 & 0.587 & 0.647 \\
\hline
\end{tabular}

\section{Statistical Analysis of Primary Data and its Finding}

In order to understand the relationships between various aspects of corporate governance and their determinants we use correlation coefficients and test the statistical significance of these coefficients. Here, we consider the major aspects of corporate governance like how many regulatory permission are required to start the business, extent of transparency and accountability in running the business, and the number of managers and professional staff at various level. On the other hand, the determinants are classified into four major categories (i) extent of risks in business, (ii) nature of the firm (i.e., whether it is a proprietorship, partnership, cooperative, private company, public company, or public listed company), (iii) infrastructure relating to information technology and computing (i.e., whether the firm has internet connectivity and the number of computers it has), and (iv) the firm's capital structure. We also use correlation coefficients and their statistical significance to examine the impact of various aspect of corporate governance on firm's performance. Here we look at a firm's performance from perspectives - (i) the initial level of profit, and (ii) whether the profit has increased over the period of time. It should, however, be pointed out that conceptually a correlation coefficient indicates only the degree of association between two variables and it does not take care of the direction of causality (i.e., which variable is the cause and which one is the effect). However, in a two-variable framework, as it is in the preset case, the problem of fixing the direction of causality may not be so important in understanding the relationship especially when the correlation coefficient is statistically significant.

- The correlation coefficients of number of regulatory permissions with respect to extent of risks in business, type of the company other than public listed and capital structure are statistically significant. This means that number of regulatory permission complied by a firm depends on its type (other than cooperative and public listed companies), availability of infrastructure facilities relating to information technology and risks in business. The firms with low risks in business or partnership, private limited or public limited in nature or having large number of computers along with internet connectivity comply with large number of regulatory permissions, whereas it is less for the firms that are proprietorship in nature. The correlation coefficients of number of regulatory permissions with respect to cooperatives, public listed companies and capital structure of the firms are not statistically significant. This means that the number of regulatory compliance does not vary with a firm's capital structure or if it is cooperative or public listed in nature.

- The correlation coefficients of extent of transparency and accountability with respect to all the variables except cooperatives and capital structure are statistically significant. This 
means that the extent of transparency and accountability of a firm depend on its type (other than cooperatives), availability of infrastructure facilities relating to information technology and risks in business. The firms with low risk in business or partnership, private limited or public limited in nature or having large number of computers along with internet connectivity have greater transparency and accountability in their business, whereas it is less for the firms that are proprietorship in nature. The correlation coefficients of transparency and accountability with respect to cooperatives and capital structure of the firms are not statistically significant. This means that the extent of transparency and accountability does not vary with a firm's capital structure or if it is cooperative in nature.

- The correlation coefficients of number of apex managers with respect to all the variables except extent of risks in business, cooperatives and capital structure are statistically significant. This means that the number of apex managers of a firm depend on its type (other than cooperatives) and availability of infrastructure facilities relating to information technology. The firms that are partnership, private limited or public limited or public listed in nature or having large number of computers along with internet connectivity have more number of apex managers in their business, whereas it is less for the firms that are proprietorship in nature. The correlation coefficients of the number of apex managers with respect to extent of risks, cooperatives and capital structure of the firms are not statistically significant. This means that the number of apex managers does not vary with a firm's capital structure or extent of risks or if it is cooperative in nature.

- The correlation coefficients of number of middle and junior level managers with respect to all the variables except partnerships, cooperatives and capital structure are statistically significant. This means that the number of middle and junior managers of a firm depend on extent of risks, its type (other than partnerships and cooperatives) and availability of infrastructure facilities relating to information technology. The firms that have low risks or are private limited or public limited or public listed in nature or having large number of computers along with internet connectivity have more number of middle and junior manager in their business, whereas it is less for the firms that are proprietorship in nature. The correlation coefficients of the number of middle and junior managers with respect to partnerships, cooperatives and capital structure of the firms are not statistically significant. This means that the number of middle and junior managers does not vary with a firm's capital structure or if it is partnership or cooperative in nature. The same can be said for middle and junior professionals

- The correlation coefficients of number of senior professionals with respect to all the variables except risks in business, partnerships, cooperatives, public listed companies and capital structure are statistically significant. This means that the number of senior professionals of a firm depend on whether it is proprietorship or private company or public company and availability of infrastructure facilities relating to information technology. The firms that are private limited or public limited in nature or having large number of computers along with internet connectivity have more number of senior professionals in their business, whereas it is less for the firms that are proprietorship in 
nature. The correlation coefficients of the number of senior professionals with respect to business risks, partnerships, cooperatives, public listed companies and capital structure of the firms are not statistically significant. This means that the number of senior professionals does not vary with a firm's business risks or capital structure or if it is partnership or cooperative or public listed in nature.

\section{Impact of Corporate Governance}

\begin{tabular}{|c|c|c|}
\hline \multicolumn{3}{|c|}{ Table XXV: Impact of Governance on Performance } \\
\hline \multirow[t]{2}{*}{ Variable } & \multicolumn{2}{|c|}{ Correlation Coefficient } \\
\hline & Profit & Increase in Profit \\
\hline Regulatory Permission(CC) & -0.074 & 0.141 \\
\hline Level of Significance & 0.010 & 0.001 \\
\hline Transparency(CC) & -0.024 & 0.126 \\
\hline Level of Significance & 0.407 & 0.001 \\
\hline Apex Manager(CC) & 0.108 & 0.243 \\
\hline Level of Significance & 0.001 & 0.001 \\
\hline Middle Manager(CC) & 0.049 & 0.049 \\
\hline Level of Significance & 0.089 & 0.083 \\
\hline Junior Manager(CC) & 0.051 & 0.073 \\
\hline Level of Significance & 0.073 & 0.009 \\
\hline Senior Professional(CC) & 0.092 & 0.167 \\
\hline Level of Significance & 0.001 & 0.001 \\
\hline Middle Professional(CC) & 0.033 & 0.162 \\
\hline Level of Significance & 0.252 & 0.001 \\
\hline Junior Professional(CC) & 0.006 & 0.127 \\
\hline Level of Significance & 0.832 & 0.001 \\
\hline Training of Employees(CC) & 0.134 & 0.084 \\
\hline Level of Significance & 0.001 & 0.003 \\
\hline Awareness of Employees(CC) & 0.060 & 0.048 \\
\hline Level of Significance & 0.037 & 0.087 \\
\hline $\begin{array}{l}\text { Suggestion } \\
\text { Employees(CC) }\end{array}$ & 0.144 & 0.227 \\
\hline Level of Significance & 0.001 & 0.001 \\
\hline
\end{tabular}

*(CC)Stands for Correlation Coefficient

**(Red coloured values are not statistically significant)

In case of level of profit, we find that the correlation coefficients of the number of regulatory permissions it complies, number of managers at various levels, number of professional managers at senior level, training of the employees, their consciousness about the firm's activities and suggestions for betterment of the firm's performance are statistically significant. 
This implies that the level of profit of a firm varies significantly with the number of regulatory permissions it complies, number of managers at various levels, number of professional managers at senior level, training of the employees, their consciousness about the firm's activities and suggestions for betterment of the firm's performance. A firm that complies with more number of regulatory permissions is likely to record lower level of profit in initial stage of its business. On the other hand, the firms with more number of managers at various levels or more number of professional managers at senior level or with regular training of the employees or greater consciousness of the employees about the firm's activities or frequent suggestions by the employees for betterment of the firm's performance record higher profit. However, the correlation coefficients of transparency and accountability and the number of professionals at middle and junior level are not statistically significant. This means that transparency and accountability and the number of professionals at middle and junior level do not have any significant impact on the level of profit of a firm.

As regards increase in profit, it is observed that the correlation coefficients of all the variables considered are statistically significant and positive. This means that the firms with larger regulatory compliance or greater transparency and accountability or more number of managers at various levels or more number of professional managers at different levels or with regular training of the employees or greater consciousness of the employees about the firm's activities or frequent suggestions by the employees for betterment of the firm's performance record higher profit experience significant increase in profitability. 


\section{Recommended Corporate Governance Norms for SME}

Based on the above findings, the following may be proposed 'corporate governance norms' for SME:
A. Prepare and Publish 'Mission Statement' of Enterprises
B. Enterprise Policy Statement to Manage Business Growth
C. Enterprise Succession Plan
D. Annual Management and Accomplishment Statements
E. Management Structure and Level of Professional Qualification as relevant to Industry
F. Method of accounting and disclosure of audited account
G. Stakeholder relations and welfare undertaken by the enterprise
H. Legal and regulatory Compliances

\subsection{Illustrations:}

\section{A. Mission Statement of Enterprises}

Explanation: The mission statement of the enterprise is the simple statement of objective of business and purpose, which is a public statement about the organization mission and commitment to its stakeholders. Such public statement asserts that the enterprise actually engages in activities that will benefit the stakeholders.

Reason for suggestion: The enterprises in the SME sector have different organizational forms as has been stated earlier. And the sector is dominated by the proprietor and partnership firms. There are also representations of private and public limited companies, though minimal in number. Therefore, the sector is dominated by informal organizations. In informal organizations as well as the small private and public companies, the organizational mission is not usually specified and work is more on ad hoc arrangement. So, it is difficult for any outsider [internal and external stakeholder] to contemplate its future course of actions. The mission statement will be an organizational objective statement in public domain which will deter the organization from taking adhoc future course of action relating to organizational future development and stakeholder management. Further, it will also provide the policy regarding stakeholder management.

How to Implement: On the implementation front, it would be challenging proposition from the perspective of 'framing the mission statement' and 'disclosure and implementation of mission statement'. It may be proposed that the 'mission statement' should be in specific number of words expressed in simple sentence. It should be clear, precise and distinctive of organizational mission and stakeholder relationship. The number of words may range from twenty-five to seventy five in a sentence. Question may rise from as to wherefrom the magic number of words comes and why a single sentence? This is based on research undertaken about the effectiveness of the mission statement in different jurisdictions. 
Researchers believe that this should be a voluntary action on the part of the organization, whereby no regulatory monitoring is required. On the other hand, the mission statement will bring manifold credibility of the organization before public life. So, the organization should adopt the appropriate means, either in electronic mode or physical, to publish the same. If the organization is undergoing modification, both the mission statements should be published simultaneously for coming six months.

\section{B. Enterprise Policy Statement to Manage Business Growth}

Explanation: The manager and proprietor of the enterprises should give annual policy statement about the business growth from the perspectives of capital deployment, management, productions/business, consolidation of the organizational structure, human resource management, business risks it would be subjected to and stakeholder relations relating to above issues [like regulator, creditor and supplier relationship with the enterprise]. The statement should also include enterprises proposed growth in coming year [within one month of the financial year beginning] and the time line within which it wants to achieve that growth.

Reason for Suggestion: Enterprise Policy Statement to Manage Business Growth will bring the required transparency in the organizational functioning and its understanding of business risk management. It will also indicate the level of professionalism the enterprise intends to adopt. Further, it will also help the creditor or other interested persons dealing with the enterprise in determination of level of business involvement they intend to develop with the enterprise. The statement of growth will further facilitate in acquiring adequate finance from the Financial Institutions. It will also be a mile stone reading against the achievement of enterprise mission statement.

How to Implement: The policy statement will provide the information in sub-categories proposed above. The statements made under this heading will be simple in nature and understandable to the common man. This is also a voluntary statement on the part of the enterprise but the appropriate regulatory authorities will keep a close look in this matter. The statement should be placed in the public domain, either in electronic form or in the nature of physical publications.

\section{Enterprise Succession Plan}

Explanations: The enterprises in the SME sector face the biggest challenge in determination of leadership succession. Enterprise succession management plan should be determined in advance giving appropriate weightage towards professional qualifications and experience in the relevant business. The succession plan has to be disclosed in advance.

Reason for Suggestion: The leadership in these enterprises is not always chosen from professionally qualified managers, as a rule rather it is a family succession. So, the aptitude, foresight, professional outlook which were available with the first generation promoter/s of enterprise might not be available with the subsequent generations of promoter/s or manager/s. So, undermining the professional skill or leadership may pose a challenge towards the growth and sustainability of the enterprise. Further, it may pose difficulty to outside stakeholder in 
building up longtime relationship with enterprises in the event of uncertainty. So, proposing the qualifications of prospective candidates or candidature will bring further transparency in enterprise future course of actions.

How to Implement: Finding the appropriate successor of leadership in the enterprise is essentially a job of existing management. Management has to lay down the qualifications and procedure for selection of appropriate successor in consultation with appropriate stakeholder, if any. The government or regulator has very limited role to play in this regard. Importantly, regulator may insist upon the disclosure of said qualifications and procedure withina time frame. It is suggested that the enterprise should reveal the candidature of successor at least six months in advance. The information of the candidature should be in the public domain, either in electronic form or otherwise through formal announcement.

\section{Annual Management and Accomplishment Statement}

Explanation: Annual Management and Accomplishment Statement is the self assessment statement as compared to the policy statement made at the beginning of the financial year. It will be made on all the sub-categories mentioned in the policy statement.

Reason for Suggestion: This statement will be in the public domain; so the interested groups will be vigilant about the enterprise performance and the factors, either within or outside the enterprise, which affected the projected growth. This will be a significant indicator for the government or regulator for assessing the role of public institutions which has failed to extend necessary support to the relevant industry/business. The information and data generated out of this exercise will help the public institutes to frame policy for the betterment of the sector.

How to Implement: The statement should be releases though the electronic medium or otherwise and made accessible to all interest groups. It is suggested that similar exercise in the line of MCA 21 may be adopted for the SME. In the survey, it has been found that large number of the enterprises has adopted information technology for their day to day business activities and also agreed to file information about the enterprise, if the facility is made available.

\section{E. Management Structure and Level of Professional Qualification as relevant to Industry}

Explanation: Management structure in the SME sector is not distinguishable from ownership. So, existing managers of the enterprises should go though regular professional training programs regarding efficient capital deployment, business risk management and organizational growth.

Reason for Suggestion: Management Structure in SME sector is pre-dominantly family based or within close group of people related to enterprise promoters. Literature across the sector has argued for induction of outside professional managers within the organization for enhancement of corporate governance. According to the researchers, this is an unsustainable proposition. First of all, it might invite agency problem and cost which may not be absorbable 
within the limited management and capital structure of the enterprise. Second, the scope of inviting professional manager within the sector is very limited due to the majority business form [e.g. proprietorship and partnership firms]. Third, there is always a strong (mis)trust that professional manager will take away the control of business from the owner. Fourth, there is limited professional training available with the existing training institutes pertaining to SME sector. Primary survey reveals that large percentage of the managers in the enterprise at the levels of senior, middle and lower management are professionally qualified. And most of them are exposed to professional training. So, instead of appointment of outside professional manager, the existing managers should be exposed to professional training and relevant course ware. The access to professional knowledge should not only be available in the simple format but also in the vernacular medium.

How to Implement: It is suggested that the government proposes to the Institutes of National importance and other similar bodies to frame appropriate training programs for the different clusters of the Industry/Business. Such training programs may be through contact or web-based interactive programs in distance mode. Further, it is suggested that the enterprises should insist on their managers to undergo through the training program at least once in a year. Enterprises are required to publish the information about the professional training of its management. It is also suggested that outside stakeholders should consider the level of professional training of the managers of the enterprise before they intend to create long term relationships.

\section{F. Method of accounting and disclosure of audited account}

Explanation: Simple and standard accounting procedures and software may be proposed and developed jointly by the Indian Institute of Chartered Accountancy and the Indian Institute of Cost Accountancy or any other Institute of similar nature suitable for this sector. This would help to bring more professionalism and transparency in the sector's financial practice and in the accounting methods.

Reason for Suggestion: Primary survey reveals that maximum number of the enterprise takes professional service from the Chartered Accounts and cost accounting firm in auditing the accounts, whereas most of the enterprises maintain financial account with help of internal staff or professional firm. So, simple web based software may reduce the cost of accounting and bring standard professional practice within the organization. If the same software is connected to a centralized server, it will be possible to collate the information from the entire country and will be easy for the government to monitor the sector health conditions.

How to Implement: Software may be developed on the parameters provided by the institutes mentioned above and may be downloadable and deployable in the cross-platform operating system. The same software may be connected to the central server to upload the data feeded in the local client. Appropriate training should be provided for the software. The same may be provided electronically. Use of vernacular with English may further facilitate in acceptability of the software. Further, the information about the accounts should be available publicly to help the outside stakeholder in building business relationship with the enterprise. 


\section{G. Stakeholder relations and Welfare undertaken by the enterprise}

Explanation: Concept of business is no more the maximization of financial interest of promoter/partner/shareholder. Rather, it goes much beyond and stands for sustainable business. The enterprise activities should be towards the benefit of the employees, consumer and creditor. Further, its activity should be environment-friendly and towards the protection of basic human rights.

Reason for Suggestion: Today, enterprises are part of social matrix. The experts maintain says that the enterprises gain access to the public money through banks and other financial institutions; find required workforce and customer from the society. It is receiving the resources from the society and redeploying its assets into the society back. Therefore, the enterprises should be responsible to act toward achieving maximum benefit to the society.

How to Implement: The enterprises are required to publish annually, through the electronic media or otherwise, the activities it has undertaken to accomplish that goal.

\section{H. Legal and regulatory Compliance}

Explanation: Legal compliance is an essential parameter for good governance practices.

Reason for Suggestion: The compliance of law ensures that external governance strengthens the internal governance structure. The corporate governance of SME's can be introduced by strengthening public Institutional framework. In turn, it will create an impact on internal organizational setup. Legal and regulatory due diligence will bring the respectability of the enterprise within the society.

How to Implement: The enterprises are required to publish annually, through the electronic media or otherwise, any ongoing litigation or other regulatory sanction that has been imposed on it.

\section{Concluding Remark}

Corporate Governance for SME is a challenging task keeping in mind the business form and nature of business it is involved in. In India, the activities of SME come under different regulatory agencies as has been discussed in the different parts of the report. Because of that they are already subjected to multiple regulators which, according to researchers, appear arduous for the SME's.

Facility and welfare of SME are mainly regulated by the Ministry of Micro, Small and Medium Scale Enterprises, whereas the business forms are under the control of Ministry of Corporate Affairs. Corporate Governance is mainly an issue pertaining to business form, their efficient and sustainable management. So, logically the Corporate Governance of SME should be a subject matter to be handled by the Ministry of Corporate Affairs.

Corporate governance of SME's should be a voluntary action on their part. The researchers strongly believe that there should not be framing of any new regulations for that purpose. But there is a need of creating awareness within the sector for adopting corporate governance and its consequent benefits. 


\section{Macrothink

The financial institutions should play a proactive role in extending support to those SME who have adopted corporate governance norms. This will catalyze the voluntary action on the part of the SME to adopt such norms.

The findings further indicate that the Ministry of Corporate Affairs (MCA) should provide the facility like MCA 21 for SME's where they can file the corporate governance feedback about their respective organization. This will project a clear picture about the conditions prevalent in the sector and what needs to be done for the sector.

The Ministry (MCA) should launch vigorous nationwide campaign regarding the benefits for transforming the SME's to Limited Liability Partnership (L.L.P) and Company. The transformation of the SME's to the formal sector will bring creditability, stability, sustainability and growth in this sector as well as the business environment in India as a whole. 


\section{References}

Accounting and Financial Reporting Guidelines for small and Medium -Sized Enterprises Level 2 Guidance, United Nations Conference on Trade and Development, United Nations, New York and Geneva, 2004, UNCTAD/ITE/TEB/2003/5

Ayan Banerjee, Capital Market Access to SMEs in India, http://ssrn.com/abstract=962033

Best Practice in SME, IFPM Centre for Corporate Governance, University of St. Gallen, Switzerland, www.ccg.Ifpm.unisg.ch last visited January 3, 2010

Bob Tricker, Corporate Governance, Principle, Policies, and Practice, Oxford University, 2009 p.145

Corporate Governance and Corporate Social Respnsibility, PriceWaterHouseCoopers, Switzerland http://www.pwc.ch/en/industry_sectors/sme_s/corporate_gov last Visited Nov 10,2009

Corporate Governance Strategy, African Development Bank, July 2007

Corporate Governance, Corporate behavior and Business Performance in the Small Business Sector, http://www.chusho.meti.go.jp/sme_english/whitepaper/1999/chapter4.html

Discussion Paper for the Expert Meeting on Good Governance for SME's, 1-2 April , 2004, TRADE/WP.8/AC.6/SEM.24/2004/4, 23 March 2004

Dr. A D Clarke, SMEs and Corporate Governance : Politics, Resources and Trincle-Down Effects presented in Corporate Law Conference, University of Queensland, 5 - 7 February, 2006

Gerald Vinten, Corporate Governance: an international state of the art, Managerial Auditing Journal 13/7 [1998] $419-431$

Indrajit Dube, Corporate Governance, Lexis nexis Butterworth, New Delhi, 2009

Jonas Gabrielsson \& Morten Huse, Corporate 'outside’ Directors in SME Boards: A call for Theoretical Reflections, presented in the Expert meeting on Good Governance for SME, 1-2 April 2004,United Nations Conference on Trade and Development, United Nations, Geneva

Joshua Abor and Charles K.D Adjasi, Corporate Governance and the small and medium enterprises sector: theory and implications, Corporate governance, Vol.7 no. 2 2007, page 112

Joshua Abor and Nicholas Biekpe, Corporate governance, ownership structure and performance of SMEs in Ghana: implication for financing opportunities, Corporate governance, Vol.7 no. 3 2007, page 228

Katarina Jagic, Corporate Social Responsibility And Eco-Social Market Economy Orinetation - A basic for good governance for SME's presented in the Expert meeting on Good Governance for SME,1-2 April 2004,United Nations Conference on Trade and Development, United Nations, Geneva 
Laura Albareda, Corporate responsibility, governance and accountability: from self regulations to co-regulations, Corporate governance, Vol. 8 no. 4 2008, page 430

Lorraine Sweeney, Corporate social responsibility in Ireland: barriers and opportunities experienced by SMEs when undertaking CSR, Corporate governance, Vol. 7 no. 4 2007, page 516

Meredith Jones et. al , research report on Corporate Governance and workplace partnership case studies, conducted by Centre for Corporate and Securities Regulations and others, The University of Melbourne, 2008, website http://cclsr.law.unimelb.edu.au

Morten Huse, Corporate Governance in Advance Market Economies: Understanding Important Contingencies, presented in the Expert meeting on Good Governance for SME, 1-2 April 2004, United Nations Conference on Trade and Development, United Nations, Geneva

Paolo Crosetto, Competition and cooperation Italian SME's go International, presented in the Expert meeting on Good Governance for SME, 1-2 April 2004,United Nations Conference on Trade and Development, United Nations, Geneva

Parthasarathi Banerjee, Corporate Governance and Competence in SME's in India, CACCI Journal, Vol 12005

Rangamohan v. Eunni, Competing in Emerging Markets: the Search for a New Paradigm, 31 W. New Eng. L. Rev. 6112009

Report of "Prime Minister Task Force on Micro, Small and Medium Enterprises, Government of India, January 2010, chaired by Mr. T.K.A. Nair

Robyn Fairman and Charlotte Yapp, Enforced Self-Regulation, Prescription and Conceptions of Compliance within small Business: The Impact of Enforcement, 27Law \& Pol'y 491 2005

Shahnawaz Mahamood, Corporate Governance and Business Ethics for SMEs in developing Countries: Challenges and Way Forwardwww.isbee.org/index.php?option=com_docman..last visited Nov 10, 2009

Thomas Steger, Corporate Governance of German SME's - A review with special regards to the situation in East Germany, Chemnitz University of Technology 